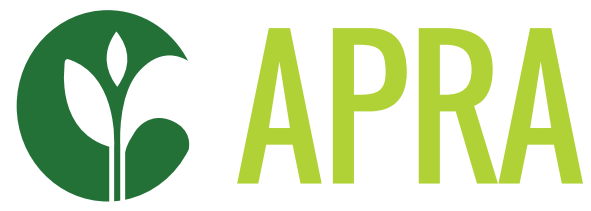

Agricultural Policy Research in Africa

\title{
AGRICULTURAL COMMERCIALISATION AND THE POLITICAL ECONOMY OF COCOA AND RICE VALUE CHAINS IN NIGERIA
}

Emmanuel Remi Aiyede 


\section{CONTENTS}

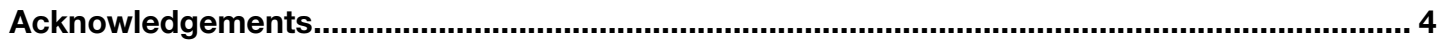

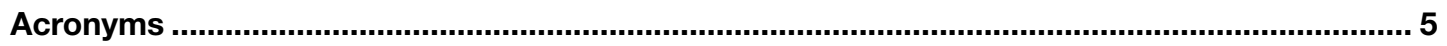

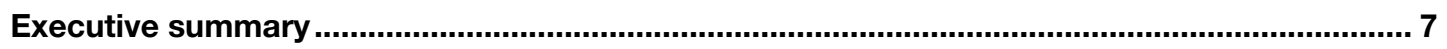

1 Background and country context

2 Theoretical framework and methodology: political settlement and agricultural

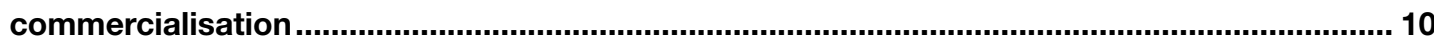

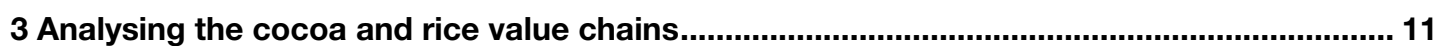

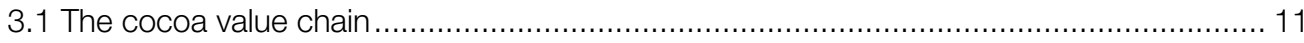

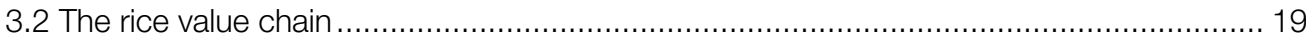

4 Public policy and the commercialisation of agriculture ..................................................... 25

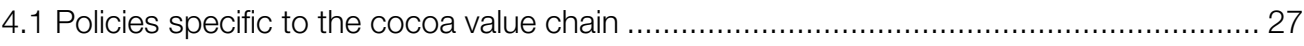

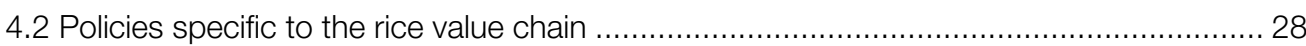

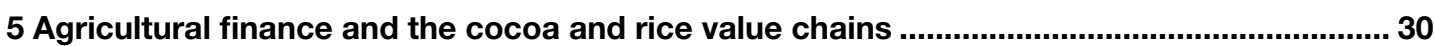

6 Donor interventions in the cocoa and rice value chains .................................................... 33

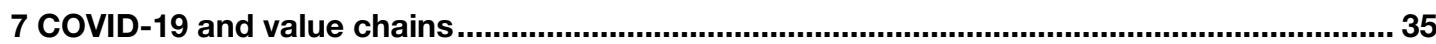

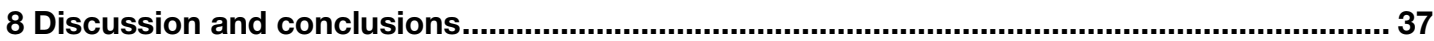

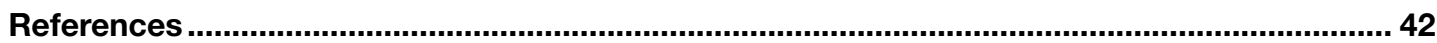

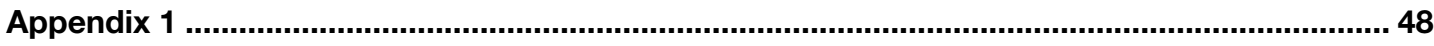

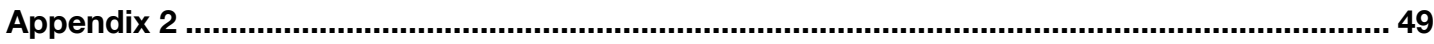

Tables

Table 3.1 Export market potentials for Nigerian cocoa ..................................................... 11

Table 4.1 Policies specific to the cocoa value chain ........................................................... 28

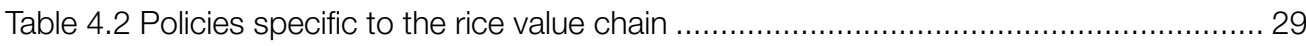

Table 5.1 Federal government initiatives in agribusiness finance........................................ 31

Table 6.1 Some bilateral/multilateral and donor interventions in agriculture........................... 34

Figures

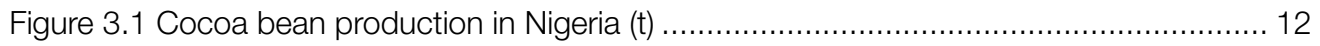

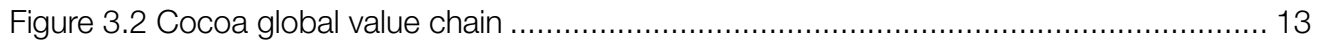

Figure 3.3 Rice production and consumption in Nigeria ............................................... 19

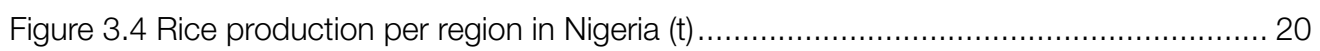

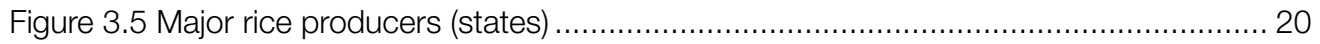




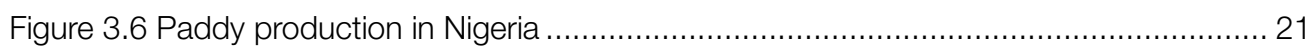

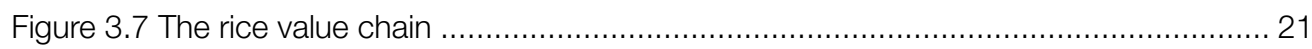

Figure 7.1 Timeline of the spread of confirmed cases ......................................... 35

Figure 7.2 Timeline of spread of cases across 36 states ....................................... 36

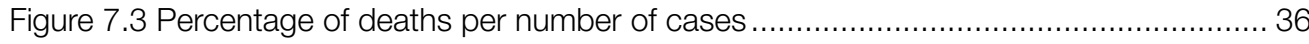




\section{ACKNOWLEDGEMENTS}

Funding for this research is provided by Agricultural Policy Research in Africa (APRA), a five-year research programme consortium funded by the Foreign, Commonwealth \& Development Office (FCDO). The programme, which is based at the Institute of Development Studies (IDS) (www.ids.ac.uk), builds on more than a decade of research and policy engagement work by the Future Agricultures Consortium (www.future-agricultures.org).

Emmanuel Remi Aiyede is Professor of Political Institutions, Governance and Public Policy in the Department of Political Science, University of Ibadan.

Many thanks to Imogen Bellwood-Howard, Benjamin Ahmed, and Lars Otto Naess for their helpful comments and insights; and to Adeola Olajide for the reference.

This working paper is funded with UK aid from the UK government (Foreign, Commonwealth \& Development Office - FCDO, formerly DFID). The opinions are the authors and do not necessarily reflect the views or policies of IDS or the UK government. 


\section{ACRONYMS}

\begin{tabular}{|c|c|}
\hline ABP & Anchor Borrowers Programme \\
\hline AfDB & African Development Bank \\
\hline AMCON & Asset Management Corporation of Nigeria \\
\hline APC & All Progressive Congress \\
\hline APP & Agriculture Promotion Policy \\
\hline ATA & Agricultural Transformation Agenda \\
\hline CACS & Commercial Agricultural Credit Scheme \\
\hline CARD & Coalition for African Rice Development \\
\hline CBN & Central Bank of Nigeria \\
\hline CCN & Cocoa Corporation of Nigeria \\
\hline CRIN & Cocoa Research Institute of Nigeria \\
\hline EEG & Export Expansion Grant \\
\hline ERG & Economic Recovery and Growth \\
\hline FAO & Food and Agriculture Organization of the United Nations \\
\hline GDP & gross domestic product \\
\hline GESS & Growth Enhancement Support Scheme \\
\hline ICCO & International Cocoa Organization \\
\hline ILO & International Labour Organization \\
\hline JICA & Japanese International Cooperation Agency \\
\hline MCF & Make Chocolate Fair \\
\hline NAFDAC & National Agency for Food and Drug Administration and Control \\
\hline NCDC & National Cocoa Development Committee \\
\hline NCS & Nigeria Custom Service \\
\hline
\end{tabular}




$\begin{array}{ll}\text { NEEDS } & \text { National Economic Empowerment and Development Strategy } \\ \text { NEPC } & \text { Nigerian Export Promotion Council } \\ \text { NGO } & \text { non-governmental organisation } \\ \text { NIRSAL } & \text { Nigerian Incentive-Based Risk Sharing System for Agricultural Lending } \\ \text { NRDS } & \text { National Rice Development Strategy } \\ \text { OECD } & \text { Organisation for Economic Co-operation and Development } \\ \text { PDP } & \text { People's Democratic Party } \\ \text { SAP } & \text { Structural Adjustment Programme } \\ \text { SON } & \text { Standard Organisation of Nigeria } \\ \text { YNC } & \text { Transnational Company } \\ \text { TNC } & \text { World Cocoa Foundation } \\ & \end{array}$


Nigeria has sought to diversify its economy away from dependence on oil as a major source of government revenue through agricultural commercialisation. Agriculture has been a priority sector because it has very high growth potential and the greatest potential for employment and export revenue. The cocoa and rice value chains are central to the government's engagement with agriculture to achieve the above objectives.

This paper sets out to investigate the underlying political economy dynamics of the commercialisation of the cocoa and rice value chains in Nigeria to inform the research of the Agricultural Policy Research in Africa (APRA) consortium. The study draws on political settlement theory to investigate agricultural commercialisation in terms of (1) smallholder farm households' shift from semi-subsistence agriculture to production primarily for the market, and (2) predominantly commercial medium or large-scale farm enterprises complementing or replacing smallholder farm households.

The paper begins by examining authoritative studies of the cocoa and rice value chains in Nigeria, as well as recent policies and regulations that govern the value chains. These are complemented with official statistics regarding the structure and performance of the value chains. Additional data is drawn from indepth interviews with knowledgeable actors, including federal and state government officials, donor agencies, rice and cocoa farmers' organisations, processors, fertiliser and seedling suppliers, agribusinesses across the value chains, and academics from the Cocoa Research Institute of Nigeria (CRIN) and the International Institute for Tropical Agriculture.

The study found a consensus among policy makers to promote agricultural commercialisation in Nigeria, which can be traced back to the adoption of structural adjustment in the 1980s. Pressures to increase the foreign exchange of agricultural products and the need for food security have ensured that a policy of commercialised agriculture has been sustained over the years. The national government has invested its power and resources more in the commercialisation of the rice value chain compared to cocoa. The goal to achieve food security seems to have placed rice above cocoa in terms of government intervention to support primary production in these value chains. Rice is a staple food with a huge gap between domestic production and demand. It is grown more widely than cocoa across Nigeria's states. Successive governments have sought to make the country self-sufficient by substituting rice imports with domestic production. Thus, commercialisation of the rice value chain is driven by rising urban markets and the government's goal to substitute imports with local production.

Large-scale investors are driving the development of the rice value chain, which is helping to improve the livelihoods of smallholders. Despite this progress, Nigeria needs to address low input farming practices and inadequate, or poor, use of fertilisers and other agro-chemicals to enhance productivity. Unlike rice, however, which is a staple, cocoa products cannot command a large market in an economy that has a very large population of poor people. It is therefore difficult for the government to create a local market for cocoa production, since it lacks control over the consumption end of the chain. Intervention by the government and the enforcement of sustainable cocoa initiatives by transnational companies (TNCs) are necessary for cocoa farming to thrive in Nigeria, given the relative dominance of large multinational companies in the downstream sector of the cocoa value chain. Smallholder farmers face structural poverty, are largely poorly organised, and voiceless in terms of price transmission, power, and influence in chain decision making. 
This paper sets out to investigate the underlying political economy dynamics of the commercialisation of the cocoa and rice value chains in Nigeria to inform the research of the Agricultural Policy Research in Africa (APRA) consortium. This background section sets out the context of agricultural commercialisation and its drivers and constraints in Nigeria.

Nigeria, Africa's most populous nation, has a land mass of 92.4 million ha. Eighty-two million ha of this land mass is considered arable. Nigeria's population was estimated at 198 million in 2018, and it is projected to be the world's third largest population by 2050. Its average annual urban population growth rate is about 6.5 per cent. It is estimated that 70 per cent of Nigeria's population will be residing in cities by 2050 (Avis 2019; Adeyemo 2019).

At independence in 1960 agriculture was the mainstay of the economy. Between 1960 and 1969 it accounted for 50 per cent of the country's gross domestic product (GDP) and provided 64.5 per cent of export revenue. Agriculture remains Nigeria's largest sector employer of labour. Crop production accounted for 90 per cent of Nigeria's agricultural output between 2012 and 2018. Nigeria's crop production consists mainly of cash crops (cocoa, rubber fruits etc) and food crops (rice, cassava, maize, and soybeans). Over the last decade, livestock production has grown at a compound annual growth rate of 4.4 per cent and accounts for an annual contribution of 7 per cent to general agricultural output. Fisheries make up for 2 per cent of output and forestry 1 per cent (KPMG 2019:4; Oxfam 2019; PWC 2017).

With the discovery and exploitation of crude oil in Nigeria, the agriculture sector's contribution to the economy witnessed steep decline, such that, currently, the sector contributes an average of 23.5 per cent to GDP and 5.1 per cent to export revenue annually. The country's dependence on oil has proven to be a curse due to the consequences of the volatile international oil market and local context of oil as an enclave economy. When the price of crude oil rises the economy grows. A drop in the price of oil often undermines government plans and budgets. Between 2011 and 2015 the economy grew at an average of 4.8 per cent. The gradual fall in the price of oil from 2014 onwards had negative effects on the economy, such that by the second quarter of 2016, the country's economy went into recession. The Buhari government introduced an Economic Recovery and Growth (ERG) plan (20172020) to restore growth.

The ERG, like other similar efforts by previous governments, sought to diversify the economy away from dependence on oil as a major source of government revenue. As in previous similar plans, agriculture has been one of the priority sectors for a number of reasons. It accounts for over 23 per cent of GDP and it employs about 40 per cent of the population. Moreover, agriculture has very high growth potential to support the economy and livelihoods of the population. Indeed, agriculture is considered central to the country's quest for food security and deemed to have the greatest potential for employment and export revenue. In recent years, economic growth has been mainly driven by non-oil sectors, such as agriculture, trade, information and communications technology, and other services (AfDB/OECD/UNDP 2014:31).

The cocoa and rice value chains are central to the government's engagement with agriculture to achieve the above objectives. Rice is Nigeria's second most consumed staple food, while cocoa is the highest export revenue earning crop. The two value chains are also central to government poverty alleviation and social investment programmes, as it looks to the agricultural sector for job creation, economic empowerment and industrial growth, economic diversification, and unlocking opportunities for global value chains.

In line with the agricultural commercialisation that began with the dissolution of marketing boards in 1986, successive Nigerian governments have, to varying degrees, promoted commercial agriculture that prioritised smallholder farmers and business investment in agriculture over direct government involvement in agricultural production. Indeed, the central ideology of consecutive governments regards the private sector as the engine of growth, and the government as a facilitator and partner in agricultural policy. As Leavy and Poulton (2007:9) explain, commercial agriculture 
differs significantly from subsistence agriculture in utilising economies of scale, specialisation, and the introduction of capital-intensive farming techniques and labour-saving technologies to achieve higher profits. The introduction of synthetic and natural resources (fertilisers, hybrid seeds, irrigation, etc.) also promotes the maximisation of crop yields per ha.

This paper examines agricultural commercialisation policies and practices as they relate to the rice and cocoa value chains in Nigeria. Specifically, it addresses the following questions:

- How have agricultural commercialisation policies and practices been born out in the cocoa and rice value chains in Nigeria? What are the evolving patterns?

- What are the roles of key stakeholders and government policies in the unfolding processes across the cocoa and rice value chains?

- What are the areas of convergence and divergence among actors in promoting agricultural commercialisation?

- Is there sustained political support for these policies?

- Is there bureaucratic regulatory capacity to keep economic actors within the expectation of the policies?

- What is the relative capacity of actors to self-organise and effectively represent their interests in the policy process?

The paper provides an overview of the political importance of each value chain, and reviews the performance of the chain for over two decades of democratic rule. It then provides a mapping of the segments of each value chain. It outlines the main technical challenges that value chain organisations have to overcome in order to ensure competitiveness. Furthermore, it examines broad policies as they relate to agricultural commercialisation, specific value chain policies, agricultural finance, and donor interventions, thereby tracing the policy trajectory across both value chains over the period. The paper unearths the political undercurrents of policy changes, the national institutional framework of policy making, and the role of donors and other global actors like multinational companies in the process of commercialisation. Beyond these institutional actors, the paper identifies the players, especially groups, at each stage of the chain, their interests, and their holding power, while exploring the political dynamics and social relations among these different actors. This includes the organisation of labour and issues related to ethnicity and unpaid care, and the different outcomes and consequences of commercialisation for different groups. In addition, the paper examines how the intersectional identities of male and female, migrants and indigenes people, and people from different ethnic groups influence access to land in instances of commercial production, and the power relations that are important to such interactions. Thus, it focuses on actors and interests, in particular, the rules and policies in terms of structure, agency, and intersectionality across social groups in the various segments of each value chain. The paper also provides early evidence of the consequences of the COVID-19 pandemic on the value chains. 


\section{THEORETICAL FRAMEWORK AND METHODOLOGY: POLITICAL SETTLEMENT AND AGRICULTURAL GOMMERCIALISATION}

The APRA framework that this paper adopts emphasises two elements. The first is the concept of agricultural commercialisation and the second is the theory of political settlement. Agricultural commercialisation is understood in terms of two shifts in movement:

\section{- Smallholder farm households shift} from semi subsistence agriculture to production primarily for the market, in the process of coming to rely increasingly on purchased inputs and perhaps also labour in their production.

\section{- Smallholder farm households are} complemented or replaced by medium or large-scale farm enterprises that are predominantly or purely commercial in nature (Poulton and Chinsinga 2018:4).

These shifts are expected to be catalysed by growing market demands in rapidly growing urban centres and export markets, or interventions by the government that seek to overcome supply-side commercialisation. The political settlement framework is one of the frameworks of analysis that attempts to overcome the shortcomings of the neopatrimonialism framework of analysis that came to dominate efforts to explain and address the governance crisis in Africa during the 1980s and 1990s. Neopatrimonialism was criticised for its inability to go beyond enumerating the pathologies of the African state, to explain variations in social and economic performances across time and space, and to account for the role of leadership and institutions in development (Aiyede and Igbafe 2018; Mkandawire 2015). The political settlement approach provides a historically and institutionally informed understanding of the ideas, institutions, actors, and relationships that are at play in determining development policy outcomes. It emphasises the role of 'leaders, elites, coalitions, and their followers in reaching agreements about the political conditions and practices they will observe' (Laws and Leftwich 2014:2).

Political settlements are the expression of a common understanding, usually forged between elites, about how power is organised and exercised. They include formal institutions for managing political and economic relations, such as electoral processes, peace agreements, parliaments, constitutions, and market regulations. But they also include informal, often unarticulated agreements that underpin a political system, such as deals between elites on the division of spoils. Political settlements establish the basic rules governing economic relations and resource allocation. (DFID 2010:22)

Political settlement theory moves away from a 'one size fits all' approach of neopatrimonialism. It examines how rents are extracted and used, as well as policy choices and the political dynamic that drives them, to explain development processes and outcomes (Kelsall 2016).

Data for the analysis was drawn largely from a systematic review of the literature on the subject matter, including a review of policy documents and regulations, official statistics, and media reports on issues regarding the structure and performance of the value chains. Additional data was drawn from 16 in-depth interviews with knowledgeable actors (see Annex), including federal and state government officials, donor agencies, rice and cocoa farmers' organisations, processors, fertiliser and seedling suppliers, agribusinesses across the value chains, and academics from the Cocoa Research Institute of Nigeria (CRIN) and International Institute for Tropical Agriculture. 


\section{ANALYSING THE COCOA AND RICE VALUE CHAINS}

\subsection{The cocoa value chain}

\subsubsection{Overview of the cocoa value chain}

Cocoa is Nigeria's major agricultural export. Other major export crops include oil seeds and oleaginous fruits, fruits and nuts, milk, cream and milk products, and spices. Nigeria is the fourth largest producer of cocoa in the world, after Cote d'Ivoire, Indonesia, and Ghana. It has a production volume of $245,000 t$ of cocoa bean per annum, covering a 6.5 per cent share of global production. Although cocoa is the main agricultural export in Nigeria, cocoa production accounts for only 0.3 per cent of the agricultural GDP (Cadoni 2013:8). Cocoa is mainly exported as beans with limited processing activities within the country. Nonetheless, it is also exported as cocoa paste and cocoa butter to the Netherlands and Russia.

Cocoa beans account for approximately 90 per cent of US\$804 million worth of Nigerian cocoa exports, while cocoa butter and cocoa paste account for US\$67 million and US\$28 million respectively. Cocoa production is projected to grow by 4 per cent per annum in coming years (NEPC 2020). According to the Nigerian export promotion council, the export markets for cocoa beans are Germany, Malaysia and the Netherlands, with untapped opportunities in Singapore and Turkey.

The Netherlands is the largest export destination for Nigerian cocoa beans. It is also the largest export destination for Nigerian cocoa butter. It still offers an untapped potential of US\$35.2 million for Nigerian cocoa beans. The Netherlands' imports of Nigerian cocoa beans and butter grew by 14 per cent on average per year during the period 2013-2017.

Agriculture is given a place of pride in Nigeria's policy of economic diversification in the ERG 2017-2020 plan. Cocoa is one of the 13 National Strategic Export Products of the federal government and is very prominent in the NEPC's zero oil plan initiative. It is expected that the local cocoa processing industry will grow and play significant role in employment generation. Cocoa accounted for 20.8 per cent of all non-oil export in Nigeria in 2018. Nigeria earned US $\$ 338.17$ million from cocoa and cocoa products in 2018 (NEPC 2020).

Cocoa is produced in two main moisture belts in the South West and South South geopolitical zones, which have a climate that supports production. These zones produce a supply of cocoa beans from October to June. This is a relatively long cocoa production period. The major cocoa producing states are Ondo, Ogun, Osun, Oyo, Edo, and Cross Rivers. Other states that produce cocoa include Kwara, Kogi, and Adamawa. Ondo state accounts for over 50 per cent of cocoa production in Nigeria. The dominant cocoa producing states are in Yoruba land in southwestern Nigeria, which accounts for over 60 per cent of cocoa production (including Ondo's production). The Nigerian cocoa sector is dominated by smallholder farmers, who number 300,000-350,000, with some commercial plantations. The area of land cultivated for cocoa production is 1.4 million ha (Nwafor, Diao and Alpuerto 2010).

Table 3.1 Export market potential for Nigerian cocoa

\begin{tabular}{|l|l|l|l|l|}
\hline & $\begin{array}{l}\text { Current exports } \\
\text { (average 2012- } \\
\text { 2016, US\$) }\end{array}$ & $\begin{array}{l}\text { Untapped } \\
\text { potential (2021, } \\
\text { US\$) }\end{array}$ & $\begin{array}{l}\text { Growth potential } \\
(\%)\end{array}$ & Major competitor \\
\hline Germany & $57,300,000$ & $100,000,000$ & +175 & Côte d'Ivoire \\
\hline Malaysia & $31,000,000$ & $72,300,000$ & +233 & Ghana \\
\hline Singapore & $2,200,000$ & $54,400,000$ & $>500$ & Ghana \\
\hline Turkey & 917,300 & $43,100,000$ & $>500$ & Côte d'Ivoire \\
\hline The Netherlands & $383,000,000$ & $35,200,000$ & +9 & Côte d'Ivoire \\
\hline
\end{tabular}

Source: NEPC (2020) 
Cocoa performance has been very uneven across the years in terms of volume of production and quality of the product, as well as yield per ha. In the 1950s and 1960s, Nigeria was the second largest producer of cocoa in the world. Cocoa production fell rapidly during the oil boom, down to an average production of 120,000t per annum between 1985 and 1989. The average annual cocoa production between 1990 and 1994 increased to 146,000 t and continued to rise to 175,000t between 2000 and 2004. After a significant rise in cocoa production in Nigeria in 2006 (485,000t), it fell in 2007 to 324,391 t and recovered in 2010, rising to $399,200 t$. It has never risen to the 2010 levels since then. Between 2010 and 2014, Nigeria's cocoa output fell to 248,000t per annum. Current data from the International Cocoa Organization (ICCO) shows that cocoa production in Nigeria declined to 210,000t in 2017, despite increasing demand for the product globally, with the country ranking sixth among cocoaproducing countries of the world. The record for 2018 is 332,200t (FAOSTAT 2020, see Figure 3.1).

The failure to achieve a consistent rise in cocoa production has been attributed to a number of factors at various segments across the value chain within Nigeria. These factors include inadequate farm inputs, such as improved seedlings and fertilisers, slow adoption of new fast-growing, better-yielding varieties of cocoa, poor funding, aging cocoa trees, inadequate extension services, limited agricultural mechanisation, the predominance of small cocoa plantations, low and declining yields due to inconsistent production patterns, disease incidence, and pest attack. The factors limiting production at the local buying agents' level include poor grading, quality control, and packaging.
The processing companies face challenges such as insufficient capital, the high cost of cocoa beans, ineffective and unfavourable government policies, the non-existence of a cocoa commodity board, and low processing capacity.

\subsubsection{Mapping the cocoa value chain}

According to the Food and Agriculture Organization of the United Nations (FAO), a food value chain refers to the 'full range of farms and firms and their successive coordinated value adding activities that produce particular raw agricultural material and transform them into particular food products sold to final consumers and disposed after use' (FAO 2014b:6). The value chain approach is particularly germane for capturing the dynamic interaction and value addition activities of key players within the chain. Figure 3.2 represents the various segments and key players in each segment in the cocoa value chain. Given the nature of cocoa as essentially an export crop in Nigeria and the dominant role of multinational companies in the value chain, it is important to examine the value chain in its global character. Five segments in the value chain are identified by Gayi and Tsowou (2016). These are cocoa production, sourcing and trading, processing, manufacturing and distribution of industrial chocolate, and retailing to consumers. Adebayo et al. (2015) identify similar segments in the cocoa value chain (cocoa production, processing, bulking and marketing, and end-use processing and marketing), while Cadoni (2013) considers the cocoa value chain as a global value chain. Thus, an analysis of the various groups identified in the cocoa value chain, governmental and non-governmental actors, can be undertaken at each segment across the chain.

Figure 3.1: Cocoa bean production in Nigeria ( $t$ )

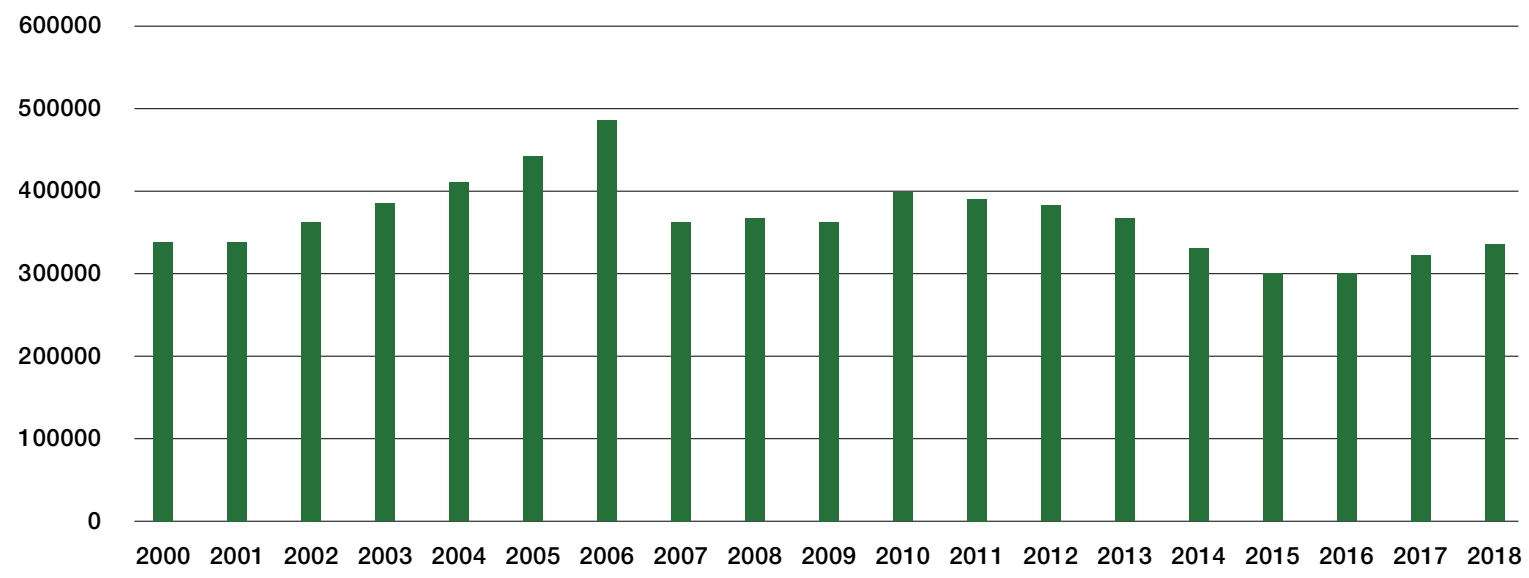

Source: FAOSTAT (2020) 


\section{Cocoa production}

The upstream production of cocoa bean is the dominant activity locally. It involves growing the trees, harvesting the pods, and fermenting and drying the beans. This upstream segment is dominated by farmers. The role and power relations among actors can be analysed around issues of land use and ownership (farm owners and labourers), agricultural inputs and productivity (multiple levels of government and private businesses), and price transmission, farmers' income, and poverty (farmers cooperatives, trading companies, processing companies, big chocolate firms, and local and international non-governmental organisations (NGOs)). Gender is a crosscutting issue in land use and ownership and farmers' income and poverty.

Cocoa is typically grown by small farmers who account for over 80 per cent of production, cultivating small patches of land of an average size of 2.5ha (PWC 2017). The cocoa tree has a gestation of period of 3-5 years before the first Harvest (there are newer seedlings of 18 months). Harvesting involves cutting the pods and splitting the pulp-covered beans, usually with a blade, and fermenting and drying. The cocoa beans are normally fermented and dried on the farm or in the producer's village. Some of the farmers depend on family labour. Usually, women and children assist with farm work. They fetch water for the spraying pumps, gather cocoa pods and break them open, process the seeds and transport them to the village for drying. The men harvest and dry them. There has been a long tradition of using non-family labour for cocoa production. This includes extended family labour and reciprocal labour or non-monetary labour, when farm owners work on farms on a rotational basis. This labour-intensive work also involves the hiring of labour by farmers. Hence, farmer-labour interactions are very important elements of cocoa production. The dynamic relations around cocoa farming has been explored by a number of scholars (Bello and Mitchell 2018; Aderinto 2013; Walker 2000a; Berry 1985).

Monetary labour became common as farmers sought to expand their farmland in response to demands for products in the international market and the incentives provided by the government to promote cocoa production for export. The engagement of migrant labour from various parts of rural Nigeria, especially from surrounding towns and villages, and from the eastern and middle belt regions of the country, led to the emergence of different labour management practices in the cocoa farms. First was the introduction of tenured labour, where migrants worked on yearly or short-term contracts and were housed and given farmland for food crops to support their families while they worked on cocoa farms. As cocoa became more profitable, migrant workers from other occupations and farmers in other crops took to cocoa farming. There were also migrant cocoa farmers from disease infected areas moving into places where cocoa was doing well. This led to the rapid increase in cocoa production in Nigeria up to the 1960s. Some labourers transited from merely working as hired hands in cocoa farms to owning their own cocoa farms by renting or buying farmland. These included non-local Yoruba migrant labour. Thus, one of the by-products of the cocoa boom of the 1950s was the commercialisation of land and the transition from labourer to farm owner through a

Figure 3.2 Cocoa global value chain

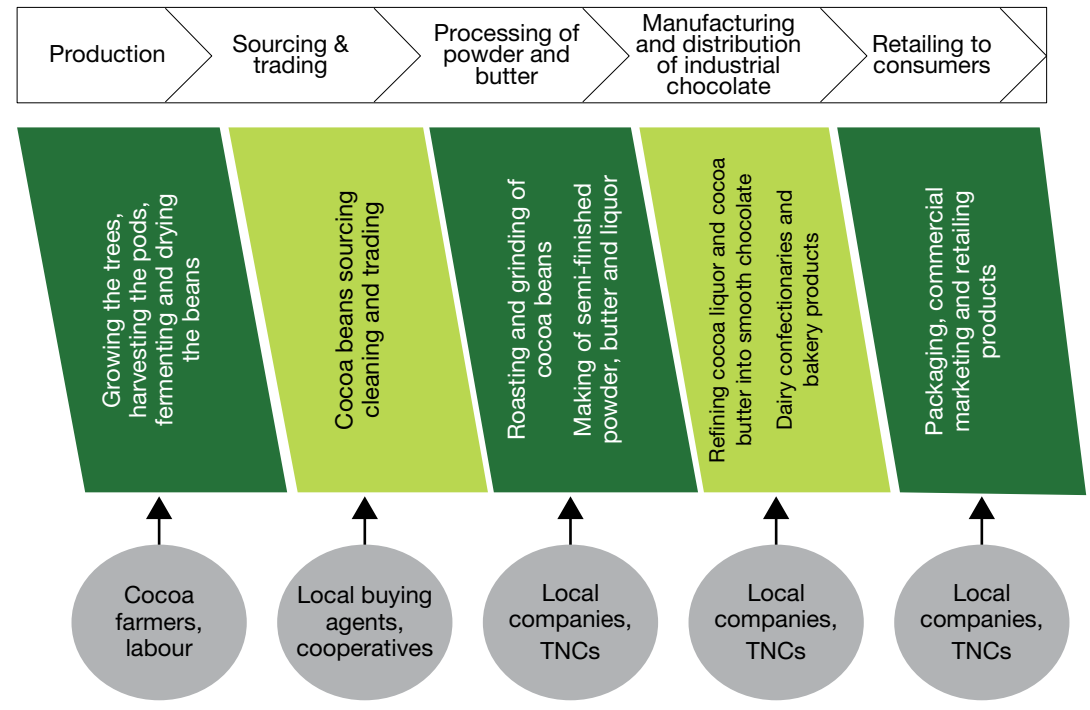

Adapted from Gayi and Tsowou (2016: 10) 
number of pathways in major cocoa producing areas (Berry 1985; Walker 2000a, 2000b; Aderinto 2013; Bello and Mitchell 2018).

Walker (2000a) provides a nuanced analysis of this development of labour relations and shows how changing patterns of labour relations were influenced by three major developments in the country and international political economy up to the 1990s. The first is the civil war, the second is the oil boom of the 1970s, and the third is the structural adjustment programme (SAP) in the 1980s and 1990s. The civil war not only put a halt to the flow of migrants, it also led to reverse migration, especially of labourers from the eastern parts of the country, particularly Igbos. This pattern of migration led to labour scarcity, a consequent rise in wages, and the dominance of daily paid contracts compared to the annual or short-term contracts of the 1960s. The oil boom catalysed another wave of migration from the rural areas to urban centres. Rural migrants followed the job opportunities in the rapidly expanding urban economy during the 1970s and 1980s, until the onset of the economic crisis. The oil boom coincided with a drastic fall in cocoa production. A similar downturn was witnessed in other agricultural produce, transforming the country's economy into a mono-mineral economy. The grave impact of this was felt with the glut in the oil market and the fiscal crisis in the 1980s and 1990s.

Within the cocoa belt farmers introduced a number of measures that transformed labour relations further, but did not stop the decrease in cocoa production. Such measures included the use of sharecropping to retain labourers. Under the sharecropping arrangement, the labourer takes responsibility of the farm from growing to harvesting, while the farmer provides inputs such as chemicals and fertilisers. The produce is then shared between the farmer and labourer, or sold and the money from the sale is shared. Farm rental for a specific number of years also intensified, as some farmers rented out their farms for a number of years and shared the harvest or the money from produce sales. In several villages, farmers organised themselves into labour pools (known as aaro) and helped one another with weeding and spraying.

The commercialisation of land led to the transformation indigene-migrant relations. Although land arrangements vary across regions in the cocoa belt, a general pattern began to emerge as the demand for cultivable land increased. This took the form of a shift from the communal ownership of land to a situation where chiefs and family heads began to lay claim to land as their private property (Aderinto 2013:6). At the same time, landowners began to assess rent on land based on the size of land cultivated rather than offering a fixed rate regardless of the size of the farm (Berry 1974:89). Then, the introduction of the Land Use Act in 1978 changed the political economy of the cocoa region, previously characterised by cooperation to one increasingly prone to conflict (Bello and Mitchell 2018:76)

Recent studies of the land situation show that there are multiple land tenure systems, despite the empowerment of state governments as custodians of land in the 1978 Act. Land insecurity has remained a recurring issue in Nigeria as a result of the multiple tenure systems. Communal ownership varies from place to place and judicial decisions have tended to recognise multiple systems without removing the tensions. Acquiring farmland constitutes a major factor in the transition from labourer to farm owner. As noted earlier, this transition has been made through share cropping, farm or land rental, inheritance, and the purchase of land. Ownership and access to cultivatable land poses a number of issues for agricultural commercialisation. This includes the challenges related to engaging multiple actors at government, community, and family levels, due to varying ownership and transfer traditions, when a farmer desires to scale up their farm holdings. The same challenges apply to any medium to largescale business that seeks to enter into the cocoa production segment of the value chain (Muyanga et al. 2019; Oxfam 2019; Bello and Mitchell 2018).

In the case of cocoa, which is a tree crop that requires a significant number of years to recoup investment, access to land is particularly challenging. With annual crops, rent may be settled annually and turnover on investment is determined in the short term. However, the situation is more complicated with cocoa. Perhaps that is why the rate of medium to large-scale investment in cocoa cultivation differs greatly from the experience of rice. In general, large-scale cocoa companies in the mid and downstream sectors of the value chain continue to rely on smallholder farmers. But vertical integration along the cocoa value chain seems to have missed out cocoa smallholder farmers in ways that raise sustainability issues. For instance, if cocoa farmers' have insufficient income from their efforts, young people may not be attracted to take up cocoa farming.

The SAP was introduced in Nigeria in 1985 by the Babangida government, after the failure of the austerity measures adopted by his predecessors to arrest the recession and fiscal crisis caused by the crash in international oil prices in the early 1980s. A major goal of the adjustment programme was the 
commercialisation of agriculture by subjecting it to market forces. A key element of the programme was the abolition of the Cocoa Board, which led to increased competition between indigenous produce buyers and their non-Nigerian counterparts. Demand for cocoa rose, generating significant increases in the price of cocoa. Cocoa prices rose from about $\$ 2,000$ per tonne in 1986 to 24,000 per tonne by August 1988, at the height of 'price wars'. The liberalisation of the local cocoa market meant that farmers could now sell their cocoa to the highest bidder, leading to an increase in their income. Labourers also earned higher wages, which enabled a number of them to transition to from labourers to farm owners. In the words of Walker (2000a:138):

One of the more significant consequences of the cocoa boom was an incredible rise in the wages of labour. The cocoa boom led to an intensification of a trend that had begun with the oil boom, when laborers began to exert their will upon cocoa farmers by demanding higher wages... One of the most dramatic consequences of the structural adjustment programme has been the emergence of a class of farmers who used to be labourers. These labourers were able to cash in on the cocoa boom to buy their own farms from cocoa farmers, some of whom were finding it difficult to maintain their farms. Those who were unable to buy cocoa farms rented farms from cocoa farmers for agreed periods of time.

(Walker 2000a:138)

Cocoa production doubled between 1985 and 1986. It rose from $92,891 \mathrm{t}$ in 1986 to $148,426 \mathrm{t}$ in 1987 , to 211,736 t in 1988, and fell to 138,940 t in 1989. It remained at about this level until 2003-2005, when cocoa production rose to an average of 251,086t per annum. Thus, the cocoa boom was very limited in scope and relatively short-lived. This has been attributed to the contradictory consequences of structural adjustment policies. While the liberalisation of the cocoa market led new entrants into trading in cocoa and facilitated the transition from labourer to farmer, it did not attract medium to large-scale investment, nor did it lead to significant farm expansion. Furthermore, the progressive devaluation of the naira and deterioration of its exchange rate, led to inflation. The liberalisation of the economy, including the cocoa market, became a two-edged sword. On the one hand it increased farmers' income from the sale of cocoa, on the other, it further raised labour wages and transportation costs. Since Nigeria depended largely on imports for inputs and goods for consumption, the general inflation of the price of imports eroded farmers' income as they had to spend more on subsistence. By 1989, the cocoa boom in Nigeria came to an end.

The absence of a regulatory agent to ensure effective certification and standards has rendered the cocoa market anarchic. Farmers have been at the mercy of local buying agents, who seem to be committed to selling at the lowest price possible. Farmers receive poor pay for their efforts with these agents determining both the price and quality of cocoa at the point of sale. As a result, young people do not see good prospects in cocoa farming. This is made worse by the long gestation period before farmers gain any return on investment and effort, in addition to the difficulties associated with access to land. Many cocoa farmers have abandoned cocoa farming for lucrative crops like oil palm and plantain, or alternative occupations, to avoid poverty.

Given the multiple pathways to access land, it is important to discuss further, the gender and ethnic dimensions of access to land in the transition from labourers to farm owners in the cocoa belt. In a study of women farmers in Yekemi, Osun state, Afolabi (2015) noted that women make this transition from labourer to farm owner when they inherit land from their husbands or parents, purchase land or rent farms from male farm owners, or engage in joint rentals. Farm rental may take the form of produce sharing. Sometimes, the transition also occurs with migrant labourers, who have endeared themselves to the community or were favoured by particular farmers. In general, access to good farmland is a pervasive problem for smallholder farmers. It is particularly challenging for female farmers and an even more severe problem for non-indigenes, who face greater discrimination in accessing land.

An important element of cocoa production, especially in terms of improving yield per ha, is pre-production inputs, such as agro-chemicals and good quality, disease resistant, early bearing, and high yielding seedings. The actors in this sub-segment of the value chain include government bodies, at both state and national levels, and private sector players, who deal in seedlings and fertilisers. The government usually provides free or subsidised inputs in the form of improved seedlings, agro-chemicals and fertilisers. The government also provides extension services. Additionally, research institutions play a role in this sub-segment, such as the CRIN, which is reputed for producing improved seedlings that they make available to farmers. Private companies involved in trading or processing cocoa beans conduct training and extension services with the aim to introduce new techniques and technologies for cocoa production (Adebayo et al. 2015). 
Cocoa cultivation, unlike other major export crops, has been the preserve of smallholder farmers. As the primary actors in the cocoa value chain, smallholder farmers face structural poverty, are largely poorly organised, and largely voiceless in terms of price transmission, power, and influence in national decision making. These challenges are even greater in the global value chain (Make Chocolate Fair (MCF) 2013). Smallholder cocoa farmers suffer from low and insecure income, are often unable to invest in their farms, cannot provide workers with proper working conditions, and, in the worst cases, are prone to use child labour. They have the least holding power among actors in the value chain and have become victims of poverty and targets for livelihood interventions from both local and international actors. The situation of cocoa farmers in Nigeria is captured by Adesina (2013a:3), the Minister for Agriculture under President Goodluck Jonathan.

The investment does not seem to [be] worth all the effort. Maintaining a cocoa farm - harvesting, fermenting, and drying - is difficult, manual labour. Conditions are rough. Many farmers live a life at or below the poverty line. Farmers have little bargaining power on price. As a result, young people are leaving cocoa for less labour-intensive jobs and better paying enterprises. What is left are ageing plantations and ageing farmers - many well over 50 years with an average life expectancy estimated at just 60.

(Adesina 2013a:3)

The concerns about equity and price transmission are important issues in relation to the holding power and social conditions of the dominant actors in this segment of the value chain. The relative inequality that straddles the global cocoa value chain is captured by the Managing Director of Oluji Cocoa Products Limited:

The point here is that the wealth accruable lies somewhere beyond production volume. Some of us are really concerned because those who benefit more from cocoa are not the farmers or the regions that grow this commodity... The global cocoa trade is controlled from outside the borders of the growers. The major players have sold the idea that we are better off remaining as providers of raw materials feed their factories and should be contented with remaining on the fringes and the rent taking that goes with that as it were. While they are building industries around our cocoa and growing their economies, we remain in the same low end we have been occupying in the global value chain since 1910, when the first batch of cocoa was shipped out of Nigeria (Ibirogba 2018:1).

Within this context, a number of players are central to shifting the dynamics of cocoa production if the supply of cocoa is to become sustainable in Nigeria. First, the national government and governments of cocoa producing states, who seek to promote cocoa production as a major source of export revenue and employment by enhancing access to production. They have done this by providing free or subsidised inputs, such as fertilisers, chemicals for pest control, and improved seedlings, as well as introducing modern farm practices through training and extension services. Some of these initiatives have been carried out through partnerships with financial institutions. The national government also interacts with cocoa farmers through state governments, its national think tank, the CRIN, and work with NGOs, including the various cocoa farmers' associations, to address issues related to yields, quality of cocoa bean and sustainability.

A number of international NGOs, such as the World Cocoa Foundation (WCF), the ICCO, MCF (2013), and the Africa Cocoa Initiative, as well as processors and chocolate manufacturers, have recently intervened in cocoa production by working with research organisations and other NGOs to address the livelihood issues of smallholder farmers. These actors have also sought to address sustainability issues, such as deforestation and climate change, as part of their commitment to responsible sourcing. They have provided skills and asset-building programmes that enable smallholder farmers and their families to strengthen their livelihoods, savings, and well-being.

\section{Sourcing and marketing}

Until 1986, marketing boards operated at the farm gate. They purchased cocoa beans from farmers at a fixed price and acted as principal sellers or exporters. With the liberalisation of cocoa bean markets in 1986, the boards were abolished. Since then, farmers or cooperatives have sold cocoa beans at buying stations directly to local buying agents or traders and brokers, who usually use the price of cocoa beans in international markets as a reference. These could be multinational companies, who buy from farmers' cooperatives or local buying agents or brokers. Recently, processors have also started to buy directly from farmers. According to a PWC study (2017), local buying agents account for 90 per cent of trading in cocoa bean, the remainder is sold through cooperatives to processors and merchants in Nigeria. 
For exported cocoa beans, at the port of destination the importer may conduct further quality checks before storing or selling the beans to cocoa processors or chocolate manufacturers. An important issue at this segment of the value chain is certification and fair pricing for produce. The abolition of the marketing boards created a vacuum that has not been effectively filled by any of the government agencies, such as Standard Organisation of Nigeria (SON) or the National Agency for Food and Drug Administration and Control (NAFDAC), or NEPC. The Federal Produce Inspection Service, the agency responsible for checking and certifying agro-allied products is ineffective because it lacks the facilities it needs to effectively carry out its responsibilities. For instance, there are too few testing laboratories for food products in the country, one in SON and the other at NAFDAC. As a result, key players in this segment of the value chain, especially the Cocoa Farmers Association, have persistently called for the return of the cocoa board in a modified form that fits into the commercial agricultural framework. The government has broached this idea as part of a policy initiative without implementation. For instance, under the Agricultural Transformation Agenda (ATA) of 2012, the government promised to set up a Cocoa Corporation of Nigeria (CCN), but it has never been established. Thus, although it was expected to open up the market for more players to participate, the liberalisation of the cocoa market, through the abolition of cocoa marketing boards, has served to consolidate and concentrate activities at the downstream segment of the value chain in the hands of a few global players. Indeed, the unequal powers of the key players have led to a situation where the initial rush to participate fizzled out due to a lack of capacity to compete. This is particularly manifest in the processing and manufacturing segments of the value chain.

In general, cocoa trading at the global and local level has become characterised by the dominance of a few transnational companies (Barry Callebaut AG (Zürich, Switzerland), Cargill Inc. (Minnesota, US), Nestle S.A. (Vevey, Switzerland), Olam International (Singapore), and Fuji Oil Company Ltd. (Osaka, Japan)). This is largely because high operating costs, including transport costs, have helped to strengthen the position of TNCs, which have better access to resources (finance and technologies) than small traders and buyers.

\section{Processing cocoa beans}

This second segment of the value chain encompasses roasting and grinding cocoa beans. Sometimes, the shell that covers the nibs is sold and used as agricultural mulch or used by fertiliser producers, thereby providing opportunities for the development of cocoa by-products. The cocoa liquor may be used directly as an ingredient for chocolate, it is pressed through a fine sieve or by using extraction solvents to obtain cocoa butter, leaving a solid material called cocoa cake or press cake, used in chocolate manufacturing. Cocoa processing previously occurred only in importing countries. It is increasingly being done in producing countries. Although cocoa bean is the dominant export in Nigeria, cocoa liquor and cocoa butter are also being exported, indicating the emergence and growth of cocoa processing in the value chain. Currently, about 30 per cent of cocoa bean produced in Nigeria is processed locally. Ninety per cent of processed cocoa derivatives in Nigeria are exported, while the remainder is used locally by beverage manufacturers. Most of these processors were previously traders and bulking agents, who have invested in processing and distribution of cocoa products locally and within the West Africa subregion. They operate in direct competition with larger multinational corporations, such as Nestlé and Cadbury. To enter into cocoa processing, corporate registration by the Corporate Affairs Commission, certification by the NAFDAC, and certification by the SON are required by law. In addition, membership in and certification by at least one of the international cocoa certification agencies is desirable.

Historically, the processing of cocoa bean was largely done in importing countries in Europe and North America, due to the need for timely delivery and the short shelf life of semi-finished chocolate products. However, in the last two decades, the first stages of the processing of cocoa bean is increasingly done in exporting countries. In Nigeria, the few companies that have entered the cocoa processing business have struggled to stay afloat. Several others have gone under. Today, Nigeria has only four surviving processing companies. In 2010, there were eight functional cocoa processing companies in Nigeria, with one under construction and two others non-functional (Adebayo et al. 2015:143). In 2018, MultiTrex Integrated Foods PLC, which had the largest cocoa processing capacity in the country $(65,000 t$ of cocoa beans per annum), was taken over by the Asset Management Corporation of Nigeria (AMCON). Many cocoa processors, who invested billions of naira in response to the governments promotion of value addition across the cocoa value chain, have incurred huge losses as a result of the hostile business environment. The industry is currently estimated to be operating at 20 to 40 per cent of its full capacity. Cocoa processing factories in Nigeria operate at a very small scale compared to their West African and global counterparts. 
According to Adefeko (2018), the high operational costs of the cocoa processing segment of the value chain are caused by several factors. These include poor power supply and the high cost of fuel, the unavailability of parts, the shortage of domain expertise, the high local interest rate, the lack of currency hedging options, the non-existence of an economy of scale, very high security costs, the inconsistent application of the Export Expansion Grant (EEG) policy, and the lack of coordination among regulatory authorities. Other challenges include an inability to target US butter markets due to pesticide residue issues and the unfavourable duty regime in Europe. Nigerian cocoa products attract a differential import duty in Europe compared to Ghana and Côte d'Ivoire. The import duty for cocoa products from these countries is 6.1 per cent for cake and 4.2 per cent for powder, whilst Nigerian cocoa butter attracts around US $\$ 300$ duty.

\section{Box 3.1: The story of Multi-Trex}

Multi-Trex Integrated Foods PLC. was incorporated in 1999 as a chocolate and confectionery manufacturing corporation. It produced cocoa liquor, cocoa cake mix, cocoa butter, cocoa powder, and chocolate powder. It also produced cocoa-based consumer products for the local market. Multi-Trex has two factories with the combined installed processing capacity of 65,000 t of cocoa per annum. It manufactured chocolate bars, drinks, and other consumer products. The company was indebted to Skye bank (now Polaris Bank) for $\$ 8.5$ billion in 2008. In 2011, when MultiTrex defaulted AMCON bought the loan facility. In June 2015, Multi-Trex's factories were shut because it was neither able to pay back its debt nor access working capital to operate. In August 2017, both AMCON and Multi-Trex reached an amicable resolution, with the management of AMCON giving the company permission to carry out all necessary activities towards the eventual commencement of operation. Although it commenced operations in the last quarter of 2017, the company is still on the Nigerian Stock Exchange's caveat list. It appears to be distressed, having defaulted listing obligations, negative retained earnings, and more.

As Gayi and Tsowou (2016:14) noted, this segment of the cocoa value chain is dominated by a few TNCs because cocoa processing is capital-intensive with high sunk costs (money that has been spent and cannot be recovered). It has experienced high horizontal market concentration with four big TNCs, namely Barry Callebaut, Cargill, ADM and Blommer Chocolate Company, controlling about 61 per cent of the market. These companies have consolidated their market share through mergers and acquisitions as they have sought to increase cost efficiency and attain greater economies of scale. High production costs have narrowed the margins for smaller companies making it difficult for those companies to survive. In 2017, Olam International acquired ADM with a Nigerian cocoa exporting subsidiary, leading it to become one of the top three players in the global cocoa processing industry. These big global brands have a competitive advantage with high research and development capacity and have continued to consolidate their hold in the industry (Manley 2017; Terazono 2014).

\section{Manufacturing (industrial chocolate production) and distribution}

Manufacturing activities include refining cocoa liquor and cocoa butter into smooth chocolate, and conching cocoa beans for utilisation in-house by manufactures of chocolate products or by downstream confectioners, dairies, and bakers. The main activities at this level in the value chain are the manufacture of chocolate confectionary, beverages, and cosmetics. This is largely done by importing countries, but it is increasingly being done by exporting countries on a small scale. As part of the cocoa rebirth and cocoa transformation agenda, the Nigerian government has tried to promote local production and distribution of finished cocoa products such as chocolates, cocoa powder, cocoa biscuits and cocoa wine. Some companies have ventured into chocolate production in recent years. Some of these companies, such as Sunshine Chocolates, Loshes Chocolate, Kalabari Gecko Chocolates, and Loom Chocolates, have been able to make modest inroads into the Nigerian domestic and export markets.

\section{Retailling to final consumers}

This segment of the chain involves the packaging, advertising, commercial marketing, and retailing of finished cocoa products, especially chocolates. Chocolate products are sold through grocery retail channels, including hypermarkets, supermarkets, convenience stores, discounters, and, increasingly, online shops. This downstream activity is the preserve of the cocoa manufacturers in the developed world, where the market for cocoa is well established and estimated to be over US $\$ 100$ billion in value. There was a spirited effort to generate demand for cocoa products across Africa, with Nigeria incorporating this promotion into the cocoa rebirth programme in early 2000s. The 'Cocoa na Chocolate' promotion initiative is the first major initiative to generate interest in domestic 
consumption of locally made cocoa products (Badiru and Akande 2017). The National Cocoa Development Committee (NCDC), set up by the government in 1999, organised a series of events to promote consumption of locally made cocoa products until it wound up. The Musa Yar'Adua/Goodluck Jonathan administration sought to establish a private sector led CCN as a replacement without success. Such events are now being organised by the Eti-Oni Development Group, which organised the first Eko Chocolate Show in Lagos in May 2019. The show was a forum for chocolate makers, chocolatiers, and chefs, as well as equipment and accessory manufacturers, restaurants, ingredient suppliers, cosmetics experts, and branding and packaging companies, among others who use cocoa as the main ingredient or part of their finished products, to exhibit their products (Okojie 2019).

\subsection{The rice value chain}

\subsubsection{Overview of the rice value chain}

According to the KPMG (2019), rice is the third most important staple food in Nigeria, with a consumption per capita of $32-35 \mathrm{~kg}$ in 2018. It accounts for 10.5 per cent of the population's average calorie intake and six per cent of household expenses. Consumption of rice has continued to rise at an average rate of 4.7 per cent per annum and has outpaced production growth, making Nigeria the second largest importer of rice after China, with 6.9 million t consumed in 2018.

The increase in the demand for rice in Nigeria coincided with the inflow of oil revenue from the 1970s. Between 1961 and 1990, rice consumption increased at an annual rate of 7.8 per cent per annum on average. Between 2007 and 2018, Nigeria recorded an annual rice deficit of about 2.4 million $t$, with 3 million $t$ of rice imported in 2018 alone. The increase in consumption of rice between 2008 and 2018 is estimated at 68.3 per cent. Most rice imports come from Thailand, India, and the US, amounting to US\$5 million daily. Rice is an essential cash crop and a major source of income for smallholder farmers, who consume 20 per cent of their total production (PWC 2018a; KPMG 2019; Okpiaifo et al. 2019).

Nigeria is Africa's second largest producer of rice, after Egypt. The rice (Oryza sativa) cultivated in Nigeria includes upland and lowland rice types. Lowland rice could be under irrigation, as in Fadama, or other forms of irrigation, such as large or medium irrigation schemes using drip, sprinkler, or free flow water, or it could be under flooded land production. Ofada (heritage varieties grown in southwest Nigeria), FARO 44 (a semi-dwarf cultivar), and other local rice varieties (i.e. short grain heritage types) are a traditional staple food consumed within rice producing communities. Rice is cultivated in all agro-ecological zones of the country, with the North West accounting for 72 per cent of total rice production. This is followed by states in the North Central geopolitical zones. A number of states in the southern part of the country, Ebonyi, Ogun, and Ekiti also produce rice in large quantities (KPMG 2019).

Figure 3.3: Rice production and consumption in Nigeria (t)

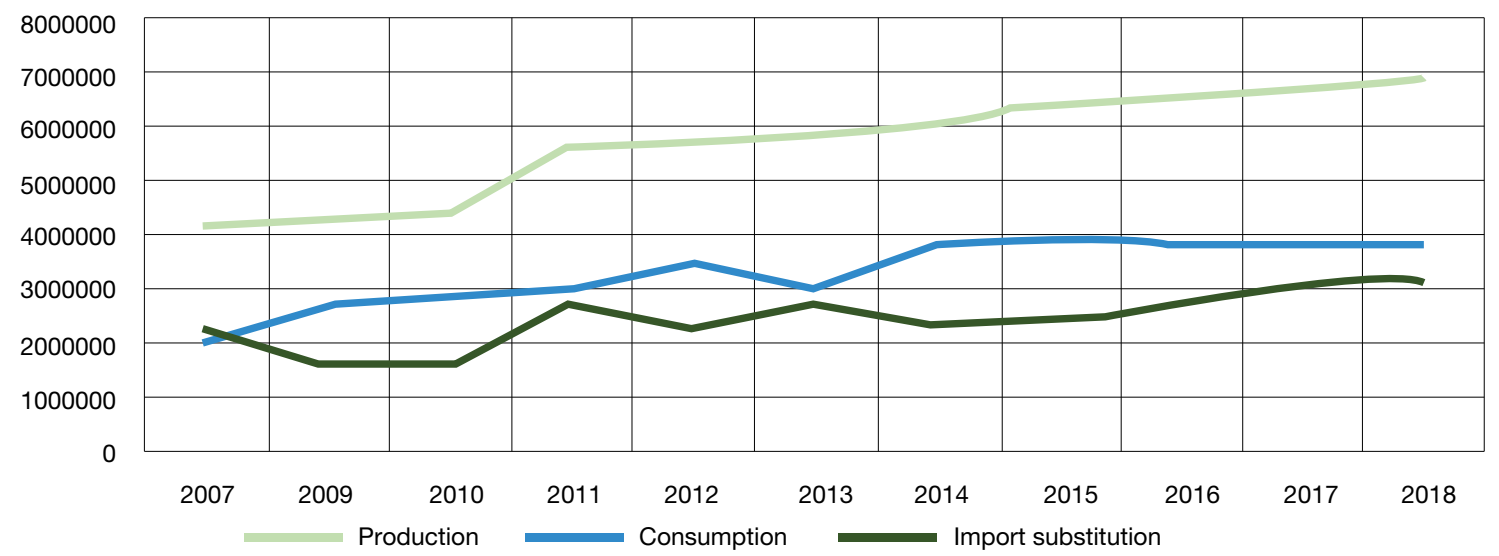

Source: Adapted from KPMG (2019) 


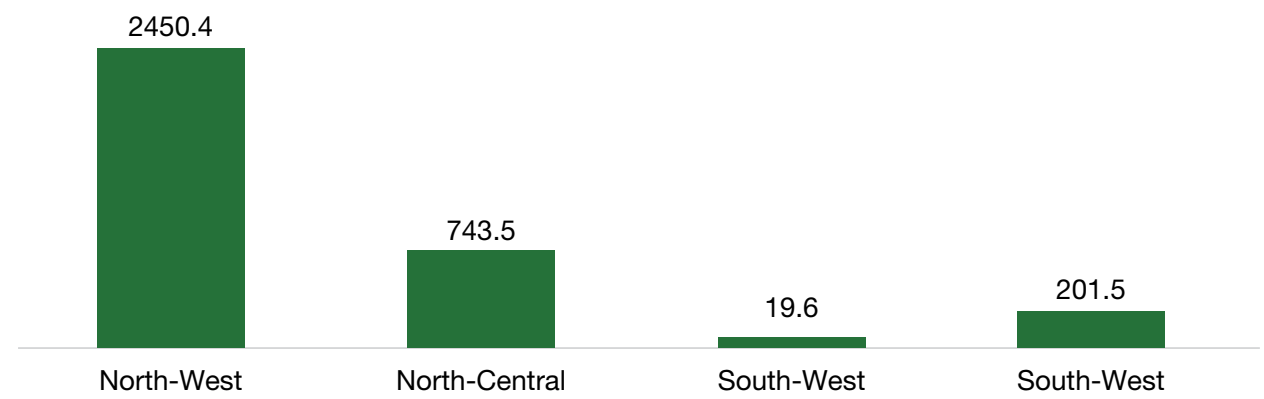

Source: Adapted from KPMG (2019)

Figure 3.5: Major rice producers (states)

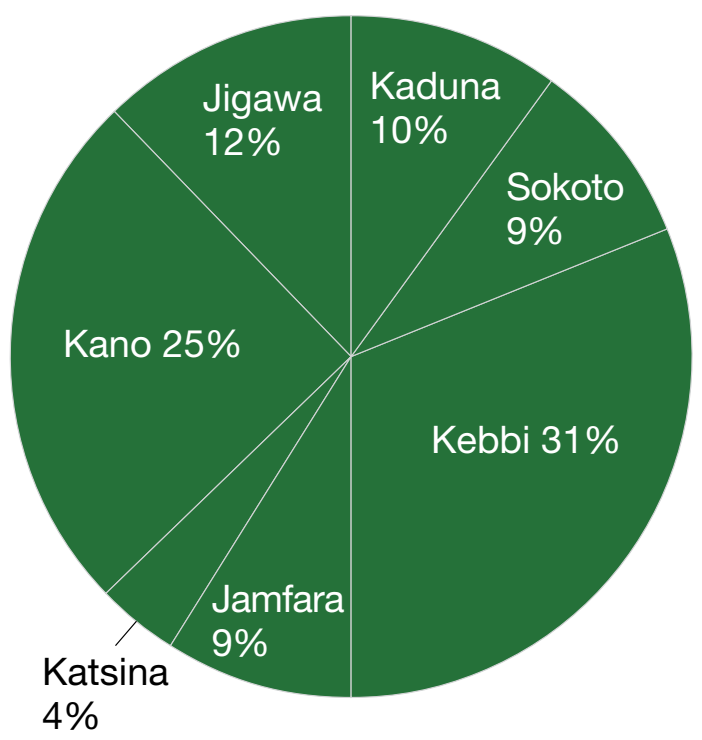

Source: Adapted from KPMG (2019)

There are multiple rice production systems in Nigeria, but rice is cultivated twice in the year. The wet season rice production lasts from October to January and accounts for 80 per cent of the total annual rice production, while the dry season is from May to July and accounts for 15-20 per cent of total rice production. Rainfed lowland cultivation is the predominant form of rice production, covering 47 per cent of land cultivated by farmers in the 2018/2019 season and over 50 per cent of rice production. Rainfed upland production accounted for 30 per cent of cultivated land for rice and 20 per cent of domestic rice production, with irrigated system production accounting for 17 per cent of cultivated areas and 27 per cent of production. Deep water and mangrove swamp account for 6 per cent of the cultivated area and 4 per cent of rice production. The dry season crop depends on the many local irrigation schemes and large dams in seven or eight states, which include the major rice producers in the North West and North Central regions. About 80 per cent of rice production is done by smallholder farmers, while 20 per cent is done by medium and large-scale farmers. The area of rice cultivated land in 2010 was 2.4 million ha. This had increased to 3.2 million ha by 2019, with rainfed lowland production accounting for 47 per cent of the cultivated area.

Nigeria's rice yield is considered the lowest in the world. Mechanisation and yields have remained low at $223.7 \mathrm{w} /$ ha and 2t/ha, respectively (PWC 2018a:4). This is below the sub-Saharan average of 2.2t/ha. Egypt and China maintain a yield of $6.9 \mathrm{t} / \mathrm{ha}$ and $8.2 \mathrm{t} / \mathrm{ha}$, respectively. An estimated 12.4 per cent of rice yield in Nigeria is wasted due to post-harvest losses (KPMG 2019:27).

With rapid population growth, rice has become central to the country's quest for food security and government policy in this area has focused on doubling production by 2020 (FRN 2009). This target has not yet been achieved. However, successive governments in the last decade have carried out a number of interventions to improve performance across the value chain, which have largely accounted for the measure of success achieved so far.

Although Nigeria remains a net importer of rice, production has increased significantly in the last two decades. FAO statistics show that Nigeria's paddy production has experienced a steady increase with potential for export (Figure 3.6).

An increase in the land area cultivated has accounted for the growth in production, rather than an increase in mechanisation. There is, however, a huge gap between paddy production and milled rice yield. 
Figure 3.6: Paddy production in Nigeria (t)

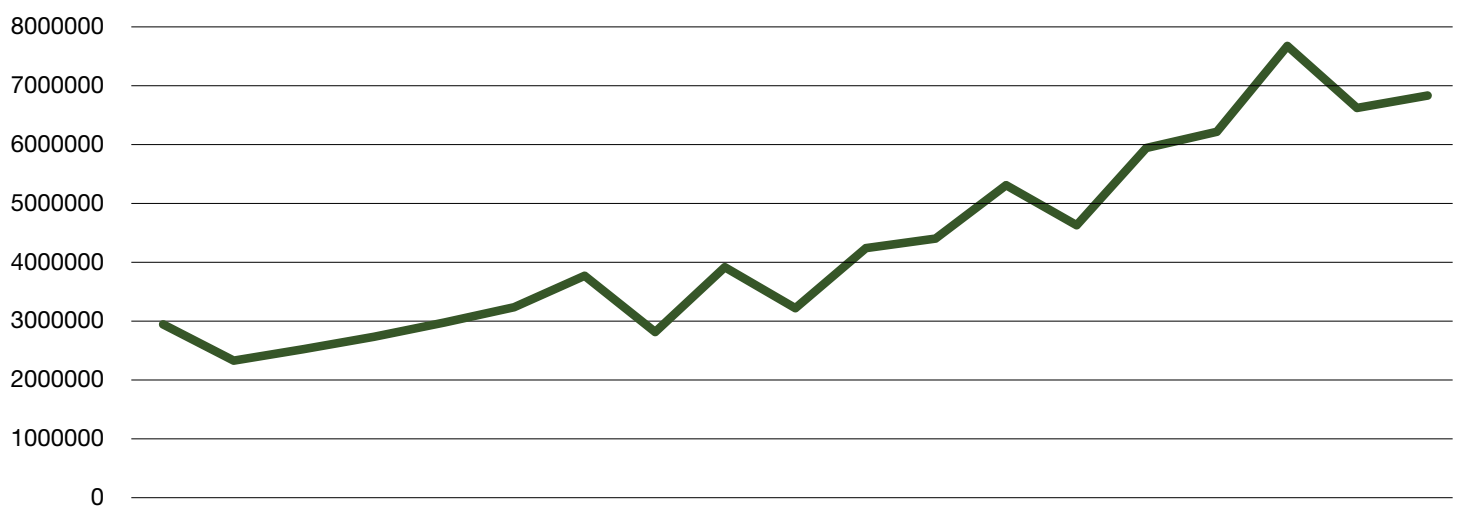

2000200120022003200420052006200720082009201020112012201320142015201620172018

Source: FAOSTAT (2020)

\subsubsection{Mapping the rice value chain}

Recent studies of the rice value chain in Nigeria have broken down the chain into a number of different elements. KPMG broke the value chain into cultivation, paddy trading/aggregation, processing, distribution, and consumption (2019). Terdoo and Feola split the value chain into production, processing, distribution and marketing, and consumption (2016), and Federal Republic of Nigeria broke down the value chain into production, post-harvest processing, and marketing (2009). This shows clearly that the major concerns regarding the rice value chain largely exclude exporting produce. This is understandable given the nature of rice as a largely staple food crop in Nigeria and the need to stem imports and guarantee food security. Government policy for the commercialisation of the rice value chain has been defined in terms of achieving import substitution with domestic production and processing, and subsequently exporting rice as a longer-term goal. Based on the literature and for the purpose of a pollical economy analysis of the value chain commercialisation, the rice value chain referenced in this paper is represented in Figure 3.7.

\section{Cultivation}

This begins with land preparation, irrigation, planting, post planting activities, such as weed and pest control, and harvesting of both straw and paddy. Smallholder farmers usually plough the fields after the first rain. Generally, tasks are allocated along gender lines. Often, the men till the soil, while women transplant seedlings to the fields and thresh the harvested crop. In some areas, men and women perform these tasks together. Pre-cultivation inputs, such as fertilisers, agro-

Figure 3.7 The rice value chain

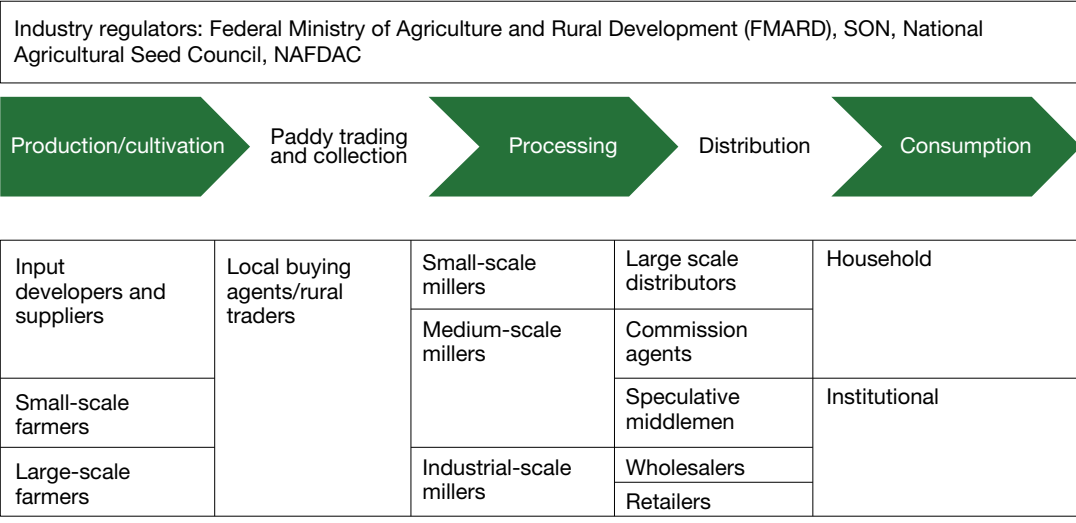

Industry associations: Rice Farmers Association of Nigeria (RIFAN), National Rice Millers Association of Nigeria (NRMAN), Rice Millers, Importers and Distributors of Nigeria, Association of Rice Investors 
chemicals, and equipment, are also important at this stage. Some farmers use organic fertilisers, including a green manuring method, by which grass is allowed to grow and is then ploughed back into the soil. However, fertilisers and herbicides are expensive, and rice is favoured as a crop because it needs fewer inputs than maize. For instance, the use of organic manure is time consuming and not widespread. Many farmers resort to buying inorganic fertilisers, which they find convenient, despite the expense. There are a number of actors in the fertiliser and agro-chemical industry that are critical for this segment of the value chain. They consist of government owned fertiliser plants and private manufacturers. Some of these manufacturers also have large-scale farms, such as Dangote Group, which is an integrated rice production agribusiness.

This segment of the value chain features three key players, the input developers and suppliers, smallholder farmers, and medium to large-scale farmers. In the last decade, as a consequence of government support for rice production, large-scale farmers, such as Dominion Farms, Olam Nigeria, PJS etc. have invested in rice production with industrial mills. The Dangote, Stallion and Elephant Groups, hitherto major rice importers, have also invested heavily in domestic rice production (KPMG 2019). Their investments have taken a number of models in terms of paddy trading and collection, and their relationship with smallholder famers. The predominant model is exemplified by Olam's nucleus farm and out-growers scheme in Nasarawa state.

In this model, the company owns and runs a nucleus farm, and provides guaranteed markets for rice farmers surrounding this nucleus farm. Olam relies on these out growers to generate paddy supplies for its rice milling factory located in Rukubi, Nasarawa state. Olam's contribution to out-growers' production includes subsidies of up to 77 per cent on the cost of improved seed varieties, training (knowledge transfer) on various aspects of rice production and agricultural best practices, and extension services. In return, out growers are expected to sell their output to Olam at market-determined prices. These terms are included in the written agreement that out growers assent to prior to engagement in the scheme (Onyekwena 2016). The total investment in rice production by these firms is over US\$2 billion and continues to grow. For instance, Dangote group has established 150,000ha of rice farmland in Jigawa, Kano, Kebbi, Nasarawa, Niger, Sokoto, and Zamfara states, as well as 10 rice mills in different parts of the country, which will deliver 1 million $\mathrm{t}$ of rice annually (Uba 2019).
Unlike cocoa, the possibilities for mechanisation of the rice value chain are enormous. Tractors, levellers, plough and tillage equipment, and harrowers can be employed for land preparation. There are planting, transplanting, and seeding machines, and combine harvesters with reaper, tripper, and stripper headers are available. There are also various grades of thresher and dryer for harvesting. Mechanisation is considered low in Nigeria at $223.7 \mathrm{w} / \mathrm{ha}$, relative to $1,938.8 \mathrm{w} / \mathrm{ha}$ in India, 1,640.9w/ha in Vietnam, and 5,965.6w/ha in China (KPMG 2019:10).

There are debates about the success of the nucleus farm model. While on the one hand it is has been projected as a successful approach to improve the conditions of smallholder farmers thanks to the technical capacity building, quality control, guaranteed market access, and gender participation; there are criticisms about the dominance of large-scale companies in decision making (ECOWAS 2018; Onyekwena 2016).

In terms of access to farmland for rice cultivation, the situation is less challenging compared to cocoa production. Smallholder commercial rice farmers rely largely on rented land. Many state governments, who are committed to boosting rice production as a staple crop for job creation and revenue generation, have been quite supportive of medium to large-scale farmers. However, a study by Oxfam in six states in northern Nigeria, observes some gender differentiation in land holding. Plots owned by women are smaller than land owned by their male counterparts. The Oxfam study found that female plot 'managers are half as likely as their male counterparts to make purchase of land, and twice as likely to rent it'. It noted further that 67 per cent of male managers reported having the right to sell the plots under their control, compared to only 31 per cent of female managers. Furthermore, only 0.5 per cent of female-managed plots are irrigated, compared to 3.5 per cent of male-managed plots (Oxfam 2019:12). These are critical gender gaps. Secure and individualised land rights can improve a farmer's ability to reap returns from investments on land, resulting in greater demand for land improvements and complementary inputs. Furthermore, the responsibilities of women as care givers tend to expand their existing challenges. Smallholder women farmers, who have to trek long distances due to poor road networks, are exposed to intimidation and sexual harassment. In some parts of northern Nigeria, where the culture restricts married women's interaction with men, women farmers suffer from lack of access to extension services (Nwokoye 2019). 
A study by ActionAid (2020) shows that women are disadvantaged in terms of access to agricultural insurance. Although agricultural insurance is poorly funded by the government, smallholder women farmers represented just 3.24 per cent of the Nigeria Agricultural Insurance Corporation farm loss compensation for the five years (2014-2018) covered by the study.

\section{Paddy trading and collection}

Middlemen traders or local buying agents play a critical role in bringing paddy from farmers to rice millers. These are usually medium-scale operators or smaller operators in large clusters in the major rice producing states, who buy paddy from farmers or paddy traders to process and sell on the market. They serve as intermediaries in the collection and bulking of paddy (Johnson and Ajibola 2016:112-116). In some of the out grower schemes they have become very active intermediaries, sourcing paddy for the mills and creating competition for large-scale companies. Onyekwena described them as a group of influential farmers and village leaders, who participate in both the Olam scheme and the open paddy market and have grown into a powerful force that has altered the structure of the market in which Olam buys rice paddies.

They offer loans to out growers, collect seeds for distribution to 'second-tier' out growers based on non-written agreements, and collect rice paddies at farm gates. As a result, Olam pays huge premiums (more than 5\%) relative to prices paid by local millers buying paddies from out growers and Olam is unable to acquire sufficient paddies for its mills, despite the heavy subsidies on seeds, free training, and extension services provided by Olam. (Onyekwena 2016:2)

\section{Processing and milling}

In Nigeria, the processing begins with parboiling the paddy rice, to ease the removal of the outer layers (husk) of the paddy or rough rice, and then a bran covering the grain seed is also removed. The parboiling process involves washing, boiling, soaking, and steaming the paddy before drying. When only the husk is removed the result is brown rice, and when further milling occurs to remove the bran, this converts it into white rice. After milling, a cleaning stage involves separating small stones from the rice, either by hand or with the use of a mechanised de-stoner. Further processing may also be carried out, especially by larger modern mills, such as polishing (buffing the white rice with glucose or talcum powder) and sifting and grading to separate any remaining small impurities and broken grains from the head rice. For the rice destined for market, a final process involves weighing and bagging the milled rice for the wholesale or retail market.

Most of the paddy rice produced by smallholder farmers is processed by cottage and small mills, with output ranging from 2-150t per day. Generally, 1t of paddy rice yields about $60-70 \mathrm{~kg}$ of parboiled rice, depending on milling efficiency, company management practice and the variety of paddy. Many of the cottage millers do not produce high quality milled rice. More integrated largescale rice mills with capacity to process paddy into parboiled rice have emerged. Some large companies that previously imported rice, such as Olam and Stallion, and other large companies like Dangote have established rice mills across the country. These mills process paddy free of sand, stones, unpleasant odour, and with fewer breakages, which competes with foreign rice in terms of quality. While whole rice is bagged and packaged for consumption, broken rice, and bran are used to produce puffed rice, rice cakes, and rice pudding.

The entrance of large-scale business into the production and milling of rice owes to a number of incentives provided by the national and state governments as part of the food security policy initiatives and commitment to running agriculture as a business. Large-scale agribusinesses, such as Olam Nigeria, Dangote Group, JOSAN Integrated Rice Farms and Mills, WEMS Agro, Kereksuk Rice, Stallion Group, Haske and Williams, and Labana Rice etc., have large mills that produce rice that competes with parboiled rice imported from Thailand in terms of quality. However, the rice produced by these agribusinesses is not price competitive. As a result, these companies and various rice farmers' association have desired, welcomed or supported government protection polices to preserve the local rice market. Such policies include import bans, and lately, border closures to reduce rice smuggling into the country, especially through the land border with the Republic of Benin. According to KPMG (2019:21), small- and mediumscale millers account for 80 per cent of processed rice, while large-scale millers (estimated to be 23 companies) account for the rest.

Many state governments have partnered with these large-scale companies, or taken initiatives on their own to invest in production and milling of rice. Some have followed the out grower model used by the large companies. Lagos state is collaborating with Osun, Ogun, Kwara, Sokoto, Benue, Borno and Kebbi states for the supply of paddy to its multi-billion naira 32t/h rice mill at Imota, which will be completed and commence operation before the end of 2021. It hopes to carry out 
this collaboration by leveraging the Anchor Borrowers Programme (ABP) of the Central Bank of Nigeria (CBN), with the rice mill as the off taker of the products (Folarin 2020).These developments, which have begun in the last 15 years, hold great promise for the development of the rice value chain in Nigeria.

Many of the state government initiatives have benefited from the intervention programmes of donors, like the World Bank and Japanese International Cooperation Agency (JICA). These interventions have provided finance and technical support and introduced simple technologies in irrigation and rice processing. They have also introduced marketing ideas to smallscale businesses across the rice value chain. These interventions usually pay particular attention to gender issues. For instance, the JICA introduced the false bottom technology to improve parboiling, which is usually the preserve of women. The traditional parboiling method often burnt, discoloured, or broke the rice, reducing its market value and earning it the name 'local rice'. Traditional parboiling also exposes women to smoke for extended periods of time, leading to health issues such as vision loss and tuberculosis (Tinsley 2012).

The labour unions have had a hard time unionising workers in the large mills. Efforts by the National Union of Food Beverage and Tobacco Employees to unionise workers have been resisted and frustrated by the companies. Casual workers often dominate the number of employees in these companies. Workers showing interest in unionisation are often threatened, victimised, or sacked. Casualisation has been a major fallout of structural adjustment in Nigeria in the 1980s (Kalejaiye 2014). Many companies operate without the benefit of unions for their workers. In June 2020, during the COVID-19 lockdown, the Nigerian police had to intervene to release 126 workers who were held hostage as forced labour for three months by Popular Farms and Mills Limited in Kano. The company, which has 41,486 member farmers in its out grower programme, as well as 65,715 ha of rice farmland with the capacity to produce 430,000t per annum, had operated in Nigeria for over 50 years. Workers in these mills work under dehumanising conditions (Adeyemi 2020).

\section{Distribution}

The distribution of rice from the cottage mills is usually done directly by independent small traders to small retailers, who sell in local markets to consumers. This is usually in the form of loose sales measured in mudu or tiya in the north, or rubber in the south, and not by weight. Nigerians depend largely on these small traders for rice. The medium and large-scale millers have branded products that pass through the formal channels, accounting for 30 per cent of rice sold to distributors. The ban on rice imports since 2015 has witnessed the growing popularity of local brands, such as Lintex, Mama's Pride and Mama's Choice by Olam, Dangote Rice, and Caprice by Stallion, among others. The ban was lifted in January 2021.

\section{Consumption}

Most Nigerian consumers, especially in the urban centres prefer the Thai parboiled rice type for its taste and texture in preparing local rice dishes (Ogunbiyi 2011; Bamidele, Abayomi and Esther 2010). Thus, import preferences among urban dwellers continues to provide competition for local well-processed rice. But many of the poorer citizens in rural and urban centres depend largely on locally produced, often low-quality, cheap rice for their consumption needs. This low-quality rice consists largely of broken and unpolished grains. 


\section{PUBLIC POLICY AND THE COMMERCIALISATION OF AGRICULTURE}

Nigeria made a break away from direct government involvement in agricultural production with the SAP in the 1980s, under military rule. Since then, successive governments, regardless of the leading party, have promoted agricultural commercialisation in line with the prevailing idea that agriculture should be viewed as a business rather than a development issue. Official government economic orientation has consistently commitment to private sector led growth since the return to democratic rule in 1999. Indeed, virtually all government documents from the National Economic Empowerment and Development Strategy (NEEDS) ${ }^{1}$ to Vision 20: 2020, the Economic Transformation Agenda and the more recent ERG plan (2017-2020), regard the commercialisation of agriculture as central to the goal of diversifying the economy away from oil. These strategies for agricultural commercialisation are intended to ensure food security, earn foreign revenue, and create jobs. Since 1999, a motley of policies that are specific to value chains, or cut across the various parts of the agricultural sector, have been developed and implemented by successive governments with varying results, as shown in the discussion of the performance of the rice and cocoa value chains earlier. This section of the paper describes the institutional contexts for agricultural policies and the specific offerings for the cocoa and rice value chains, analysing the dynamic interaction of actors in the processes.

It is important to note that agricultural policy is in the concurrent legislative list of the 1999 Constitution, which means it is an area in which both the federal and the 36 state level governments can legislate and exercise expenditure responsibilities. Under such circumstances, the federal government provides policy leadership and incentives for states to follow its lead. However, the state governments have liberty to toe the line charted by the federal government or chart their own independent courses. Naturally, given the diversity of the country in terms of climatic condition and soil texture, crops vary across the country's vast land mass. This is demonstrated by the cultivation of cocoa, which occurs in 14 states, with a concentration in six states, and rice, which is cultivated in virtually every state of the country, but is concentrated in 20 states. Both levels of government have to engage (incorporating the local governments) in delivering effective agricultural policy.

Given the diversity and varying priorities of the governments, collaboration and conflict have characterised the interactions among the state governments and federal government regarding agricultural policies. This has consequences for policy implementation. As the Agricultural Transformation policy put it:

\begin{abstract}
Though the two tiers of government - federal and state - have authority over agriculture, collaboration has not always been smooth, nor desirable results generated. Therefore, in order to ensure full potential henceforth, both parties have to focus on greater collaboration, implementing policies jointly approved at the National Council on Agriculture.

(FMARD 2011:29)
\end{abstract}

The National Council on Agriculture is the intergovernmental forum for interaction, policy harmonisation, and collaboration and cooperation among the tiers of government involved in implementing agricultural policy. Each government has a host of institutions that make and implement agricultural policy, the dominant institutions being the ministries of agriculture and rural development.

At the return to democratic rule in 1999, Nigeria embarked on a massive economic and governance reform programme under President Olusegun Obasanjo. This was due to the crisis of governance and economic mismanagement that had resulted in the prolonged stay of the military in government. The government inherited a number of agricultural policies whose salience were undermined by the protracted governance crisis. These policies can be traced back to the immediate post-independence period to include the setting up of the National Cereals Research Institute, the National Accelerated Food Production Programme, the Agriculture Development Programme, the River Basin Development Authorities, Operation Feed the Nation, the Green Revolution, the Directorate for Food, Roads and Rural infrastructure, the Bank of 
Agriculture, and many others (Odukoya 2020; GyimahBrempong, Johnson and Tashima 2016).

In the first decade of democratic rule, public policies were driven by concerns about deepening poverty and the goal of poverty reduction. This was in line with the poverty reduction strategic documents that became popular in developing countries, following the failures the SAPs in the 1990s. The first major policy initiative of the then new President Obasanjo government was the NEEDS. The main aspects of the policy that related to agriculture were to achieve self-sufficiency in food production, target a 6 per cent annual growth in agriculture, cultivate improved, higher-yielding crop varieties, and support agricultural research training. The policy intended for businesses to provide credit and agricultural inputs, such as seeds, fertilisers and machinery, to help achieve food security. This was followed by the Vision 20: 2020 document, which sought to make Nigeria the twentieth largest economy in the world by 2020 and to transform agriculture into a sustainable and profitable sector. Other major strategies include the ERG (2017-2020), which came on the heels of the economic recession that the All Progressives Congress (APC) party inherited from the defeated Peoples Democratic Party (PDP) in the 2015 general election. The latest Economic Sustainability Plan (2020) was developed in response to the dramatic consequences of the COVID-19 pandemic in 2020. All of these major initiatives gave agriculture a central role in creating jobs, ensuring food security, and generating foreign revenue.

After several piecemeal policy initiatives in the agricultural sector since the return to democratic rule in 1999, a major reform initiative for agriculture came with the implementation of the ATA 2011-2015. The ATA was built on the principle that 'agriculture is a business and therefore should be driven by the private sector'. The role of government was to support it. The main priority of the policy was to 'restart the clock' and to re-engage key stakeholders in Nigerian agriculture to view agriculture as a self-sustaining business on which the economy could be built. This general thrust of agricultural policy merely consolidates the deregulation of the economy that came with the SAP in 1986. Thus, regardless of the party in government, the orientation of agricultural policy has been to promote private sector participation. In the words of Adesina (2013a:6), 'agriculture is viewed as a business that can provide a reasonable basis for further wealth and job growth in Nigeria'.

The second dimension of agricultural policy is the focus on a value chain approach. Closing the productivity and value addition gap within the value chains also includes tackling related input, financing, storage, transport, and market access issues present in key value chains. Under this approach, a number of policies and programmes have been rolled out to target the different segments of value chains. Some of these target specific value chains, while others apply to relevant segments across different value chains. The value chain approach is informed by the desire to transform Nigeria into an agro-industrial economy. Some of the initiatives that target the various segments across Nigeria's agricultural value chains include agricultural insurance and financing schemes, such as the EEG, the Growth Enhancement Support Scheme (GESS), the Nigerian Incentive-Based Risk Sharing System for Agricultural Lending (NIRSAL), designed by the CBN to lower lending risk, and the ABP.

In general, the agricultural sector has been an arena of policy activism in which similar, if not identical, policies and projects are given new nomenclatures with emphasis on the need to improve efficiency and reduce corruption in implementation. The PDP, which governed between 1999 and 2015, pursued a business oriented agricultural policy, although it continued with subsidies on agricultural inputs. The PDP government supplied subsidised inputs directly to farmers and later introduced the e-wallet and voucher programme to engage the private sector in supplying the inputs under the GESS programme of the ATA. The APC, which assumed power in 2015, has sought to supply these inputs to farmers through the active engagement of the private sector under its ABP. The introduction of the e-wallet and voucher programme by the PDP government, under Goodluck Jonathan, was purportedly done to reduce corruption and incorporate the private sector into the subsidy regime to distribute inputs to farmers. According to Adesina (2013a:1):

\footnotetext{
The system was corrupt and undermined the private sector. It did not deliver fertilizers to genuine farmers. Instead, rich and powerful political farmers hijacked the subsidized fertilizers. As a result, no more than $11 \%$ of all farmers in the country got the fertilizers distributed by the government. (Adesina 2013a:1)
}

Adesina announced the success of the new method of distributing subsidised fertilisers until the PDP 
government was replaced by the APC, with Audu Ogbeh replacing Adesina as Minister of Agriculture. Audu Ogbeh stopped the programme when he assumed office because it was fraught with corruption allegations. According to Ogbeh, the PDP owed the agro-dealers 76 billion. He insisted he would work out a new modality for the implementation of the scheme. Thus, the ABP initiative replaced the e-wallet and voucher system of the GESS (Falaju 2019). The ABP has been praised by the current APC government as very successful. Yet, there are claims that the process is riddled with corruption. It seems to be another version of the GESS, an APC version. One difference, however, is that while the GESS was under the supervision of the Ministry of Agriculture, the ABP is a product of the CBN, under Governor Godwin Emefiele, who has been very active in the agricultural sector. This activism of the $\mathrm{CBN}$ is very visible in agricultural finance.

A look at the Agriculture Promotion Policy (APP), which constitutes the major policy document of the APC, shows very little difference from the ATA of the Jonathan Presidency. Indeed, in the foreword to the document, Audu Ogbeh stated explicitly that the APP intended to 'refresh the strategy' of the ATA because Nigeria still imports a 'significant amount of food' and is 'not earning significant foreign exchange from agriculture'. ${ }^{2}$ The Economic Sustainability Plan is a modification of the ERG to address the fallouts from the COVID-19 pandemic.

The leadership vision and commitment has been very critical in policy making at all levels. A good example is the intervention in cocoa, which has not been as consistently spirited and sustained as policy interventions for rice, largely because its production is confined to the cocoa belt in the South West and Cross River state, although 14 states are officially recognised as cocoa producing. Cocoa production has received significant attention when leaders in government have close relations with cocoa producing areas. This was the case under President Olusegun Obasanjo's administration and under President Jonathan, with Akinwunmi Adesina as Minister of Agriculture. ${ }^{3}$ The entrance of Audu Ogbeh as Minister of Agriculture also saw the rise of yam as an important commodity being promoted for export (Godwin 2017).

Some of the initiatives have been implemented without a clear show of commitment. Their implementation has been either slow in taking off or carried out in fits and starts. A very important policy like the EEG, for instance, is traceable to the 1986 Export Incentives and Miscellaneous Provisions Act, which included the Export Development Fund, the EEG and the Export Adjustment Scheme Fund. Of these initiatives introduced to accelerate export volume and enable exporters to diversify their export products and market coverage, only the EEG was in operation up to 2013. Even so, the EEG was suspended in 2013 due to perceived abuse by beneficiaries in claiming the grant. The 1986 law was amended with the Dedicated Export Funding Incentive in the Export (Incentives and Miscellaneous Provisions) Act no. 65 of 1992. The Act was again redesigned in 2005 and administered by the Nigeria Custom Service (NCS).

The EEG was initially paid to non-oil exporters in cash to reduce production, distribution, and logistics costs to make their goods competitive in the international market. At the time, it was usually 10-30 per cent of the freight on board value of the products being exported with confirmation that the proceeds had been repatriated. From 1999, it was converted to a Negotiable Duty Credit Certificate, issued by the NCS, to settle or reduce import and exercise duties. In spite of these measures, the government continued to levy all raw or unprocessed export commodities, whether in mineral or agriculture. In addition, the government owed 270 exporters arrears of EEG from between 2007 and 2016 (Eze 2019).

In the case of cocoa, there is a tension between the drive to export in general and the drive for value addition across the chain, the latter being targeted at the domestic market. In the end, Nigeria has not been able to compete with Ghana and Cote d'Ivoire in cocoa bean export or in midstream processing (grinding) as a result of these conflicting policies. Naturally, the drive for revenue means that levies are often collected, while bureaucratic bottlenecks render the grants slow in coming. In the bid to resuscitate the EEG in 2017, the government allocated 20 billion in its 2017 budget to address the over 150 billion backlog of EEG claims from 2013 (Abayomi 2019).

\subsection{Policies specific to the cocoa value chain}

As noted earlier, although cocoa remains Nigeria's major export crop, efforts to revive cocoa production have faltered. This is evident when cocoa production in Nigeria is compared with its West African competitors, Ghana and Cote d'Ivoire, which have performed better and have remained the top two cocoa producing countries globally. Policy initiatives in the cocoa sector gained an upswing during the administration of President Olusegun Obasanjo, who introduced a 
number of initiatives to advance cocoa production and sought to develop the mid and downstream segments of the value chain. He introduced the National Cocoa Development Programme and set up the NCDC to oversee the development of the value chain. The NCDC sought to grow the domestic market for cocoa products and encourage the manufacture of chocolates and other cocoa products.

A Cocoa Transformation Plan (CTP) was part of the ATA under President Jonathan. The plan sought to rehabilitate old and moribund cocoa farms and plant new farms. It also sought to establish 12 agro-export conditioning centres (two centres per geo-political zone). The CTP sought to establish a strong institutional governance structure for the Nigerian cocoa industry through a sustainable public private partnership platform, the CCN.

\subsection{Policies specific to the rice value chailn}

In 2009, Nigeria developed its NRDS as one of the pilot countries of the Coalition for Africa Rice Development (CARD). The objective of the strategy was to double rice production from 3.4 million $t$ of paddy in 2007 to 12.85 million $t$ in 2018. It hoped to move from import substitution to rice export. In line with this strategy, the government introduced a number of initiatives to support growth in every segment of the value chain (KPMG 2019).

The government has provided tax incentives for companies involved in the rice industry, introduced agricultural implement and mechanisation schemes, and developed the presidential fertiliser initiative.

Table 4.1: Policies specific to the cocoa value chain

\begin{tabular}{|c|c|c|c|}
\hline Policy name & Year & Policy thrust & Govt. party \\
\hline $\begin{array}{l}\text { Accession to } \\
\text { International Cocoa } \\
\text { Agreement }\end{array}$ & 2018 & $\begin{array}{l}\text { The Agreement was adopted on } 25 \text { June } 2010 \text { in } \\
\text { Geneva at the United Nations Cocoa Conference } \\
\text { for the Negotiation of a Successor Agreement to the } \\
\text { International Cocoa Agreement, } 2001 .\end{array}$ & Agreement \\
\hline $\begin{array}{l}\text { International Cocoa } \\
\text { Summit }\end{array}$ & 2017 & $\begin{array}{l}\text { Held 28-31 August } 2017 \text { in Abuja with the theme: } \\
\text { 'Cocoa, a Strategic Commodity for National Economic } \\
\text { Development'. To drive the attainment of the } \\
500,000 \text { t target by } 2021 \text { and agree a } 10 \text {-year cocoa } \\
\text { development road map to } 1 \text { million } t .\end{array}$ & \\
\hline $\begin{array}{l}\text { Cocoa Transformation } \\
\text { Plan (CTP) }\end{array}$ & 2012 & $\begin{array}{l}\text { The CTP sought to grow Nigeria's share of the world } \\
\text { cocoa market by increasing output to } 500,000 t \text {, } \\
\text { improve incomes for } 250,000 \text { farm households, } \\
\text { and create } 390,000 \text { new jobs along the value chain, } \\
\text { through increased production, processing, value } \\
\text { addition, and marketing activities. }\end{array}$ & PDP \\
\hline $\begin{array}{l}\text { National Cocoa } \\
\text { Development } \\
\text { Programme (Cocoa } \\
\text { Rebirth) }\end{array}$ & 2000 & $\begin{array}{l}\text { The goal was to rehabilitate 15,000ha of cocoa } \\
\text { plantation annually. The Programme set up the NCDC } \\
\text { to provide basic farming inputs to cocoa farmers, } \\
\text { organise training on cocoa rehabilitation techniques, } \\
\text { cocoa fermentation, and nursery management } \\
\text { practices, and distribute improved varieties of seedlings } \\
\text { and pods from the Cocoa Research Institute of Nigeria. } \\
\text { These provisions were intended to be delivered through } \\
\text { the Cocoa Development Units or Tree Crop Units to all } \\
\text { cocoa producing states in Nigeria. The NCDC created } \\
\text { the festival of 'Cocoa Rebirth' in } 2005 \text {, which was } \\
\text { held annually and hosted in rotation by the } 14 \text { cocoa } \\
\text { producing states in Nigeria to promote awareness and } \\
\text { use of cocoa products in Nigeria. }\end{array}$ & $\begin{array}{l}\text { PDP } \\
\\
\\
\end{array}$ \\
\hline
\end{tabular}

Source: Authors' own 
In 2015, the CBN banned the use of foreign exchange to pay for rice imports and backed loans of at least \#40 billion (US\$130 million) to help smallholders boost output. It also banned rice imports across land borders and kept hefty 70 per cent tariffs on imports coming through the ports. In August 2019, it closed borders altogether to stamp out the smuggling of imported rice from neighbouring Benin and Togo. Table 4.2 provides a summary of initiatives in the rice value chain.

Subnational government initiatives in the rice value chain have taken the form of facilitating access to land for medium and large-scale agribusinesses that are interested in investing in rice production. From CrossRiver to Lagos to Kebbi and Nasarawa, large expanses of land have been cultivated by these companies as earlier detailed. Furthermore, a number of states have entered partnerships with these companies, while others have invested in rice production and processing to increase rice availability. Lagos state partnered with Kebbi for the production of Lake Rice, which it sells at a subsidised rate. Ebonyi state set aside 54,000ha for massive rice cultivation in 2016 and introduced a oneman-one-hectare scheme with which it has supported local farmers with soft loans (KPMG 2019)

Table 4.2: Policies specific to the rice value chain

\begin{tabular}{|c|c|c|c|}
\hline Policy name & Year & Policy thrust & Govt. party \\
\hline Border closure & 2019 & $\begin{array}{l}\text { On } 20 \text { August 2019, Nigeria partially closed its land borders } \\
\text { with Benin, Togo, Niger, Cameroon, and Chad to curb the level } \\
\text { of smuggled goods into the country, especially staple food } \\
\text { commodities like rice, cooking (vegetable) oil, poultry, tomato, } \\
\text { flour, and pasta. The closure of Nigeria's land borders was } \\
\text { subsequently consolidated - with further restrictions on imports } \\
\text { and exports through land borders. }\end{array}$ & APC \\
\hline Tax incentives & $\begin{array}{l}2001- \\
\text { date }\end{array}$ & $\begin{array}{l}\text { - } \quad \text { Corporate income tax holidays of 3-5 years for companies } \\
\text { involved in rice milling and rice powder. } \\
\text { - } \quad \text { VAT exemptions on the sale of basic food items, farming } \\
\text { machinery, and farming and transportation equipment, such } \\
\text { as tractors, ploughs, agricultural equipment, and implements. } \\
\text { - } \quad \text { Export incentives for rice export. } \\
\text { Tax deductible expenditure on research and development, } \\
\text { less than } 10 \text { per cent of total profit of company. } \\
\text { Capital allowance: accelerated claim of capital agricultural } \\
\text { plant and equipment in gas fired rice production. }\end{array}$ & PDP/APC \\
\hline $\begin{array}{l}\text { Import quotas and } \\
\text { bans }\end{array}$ & 2015-date & $\begin{array}{l}\text { Since } 2015 \text { Nigeria has imposed a } 10 \text { per cent tariff and a } 60 \text { per } \\
\text { cent levy (totalling } 70 \text { per cent) on imported rice (arriving by sea). } \\
\text { There is also a ban on rice imports through land borders. }\end{array}$ & APC \\
\hline $\begin{array}{l}\text { Mechanisation } \\
\text { implementation } \\
\text { programme }\end{array}$ & 2014 & $\begin{array}{l}\text { Hiring centres were established through government partnerships } \\
\text { with financial institutions, agro-machinery vendors, and service } \\
\text { providers. Commercial funding is provided at an interest rate of } 9 \\
\text { per cent with payment spread over four years }\end{array}$ & PDP \\
\hline $\begin{array}{l}\text { Rice value chain } \\
\text { transformation plan }\end{array}$ & 2012 & $\begin{array}{l}\text { - Increase the competitiveness of local rice along the value } \\
\text { chain. } \\
\text { Expand access to inputs such as fertiliser and agro- } \\
\text { chemicals and increase use of quality seeds. } \\
\text { - Promote modern practices and management in threshing, } \\
\text { drying, and milling. }\end{array}$ & PDP \\
\hline $\begin{array}{l}\text { National Rice } \\
\text { Development } \\
\text { Strategy (NRDS) }\end{array}$ & 2009 & $\begin{array}{l}\text { To increase rice production in Nigeria from } 3.4 \text { million t in } 2007 \\
\text { to } 12.85 \text { million t by } 2018 \text { and close the huge gap between } \\
\text { production of paddy and processing by addressing issues across } \\
\text { segments of the value chain. }\end{array}$ & PDP \\
\hline $\begin{array}{l}\text { Presidential Rice } \\
\text { Initiative }\end{array}$ & 1999 & $\begin{array}{l}\text { - } \quad \text { Address the widening demand-supply gap and attain self- } \\
\text { sufficiency in rice production in } 2005 \text { and increase rice } \\
\text { exports by } 2007 \text {. } \\
\text { - Improve access to rice or R-Box technology at a } 50 \text { per cent } \\
\text { subsidised rate. } \\
\text { - Ensure production and distribution of quality certified seeds. }\end{array}$ & PDP \\
\hline
\end{tabular}




\section{AGRICULTURAL FINANCE AND THE COCOA AND RICE VALUE CHAINS}

In 2003, Nigeria signed the Maputo Declaration to allocate 10 per cent of its annual budget to the development of agriculture in a bid to promote food security and maximise growth. Nigeria also signed the resulting Comprehensive Africa Agricultural Development Programme in 2009 and formulated the National Agricultural Investment Plan in 2010 as the country's framework for its implementation. Using this benchmark, Nigeria is yet to allocate sufficient funds to agriculture. From 2017 to 2019, the budgetary allocation to agriculture has been less than 3 per cent on average. Furthermore, Nigeria reduced its budgetary allocation to the agricultural sector by 47 per cent from b203 billion in 2018 to 107 billion in 2019. The government's budget for agriculture has remained dismally low given the role of agriculture in food security, export revenue, growth, and job creation. Many of the state governments have not done better. Indeed, a significant size of the budgetary allocation to agriculture has come from donor financing at the state level (Oxfam Nigeria 2019).

Commercial banks have not been a reliable source of finance for smallholder farmers either. Inadequate capital base, poor project appraisal by banks, lack of adequate collateral, the high cost of administering small loans, loan diversion by farmers, and the limited amount of loans guaranteed by the Agricultural Credit Guarantee Scheme Fund account for this ongoing situation (Oyakhilomen et al. 2012). For instance, the volume of bank loans to the agricultural sector was 3.26 per cent and 3.36 per cent in 2016 and 2017 , respectively. In the second quarter of 2019 , it was only 4.2 per cent, while 29 per cent of private sector credit went to oil and gas, and manufacturing received 15.3 per cent (NIRSAL 2020). It is for this reason that a number of intervention schemes to finance agribusiness have been put in place by the government through the Ministry of Agriculture, the Bank of Agriculture, and CBN. These schemes are intended to increase banks' financing to the agricultural sector through loans targeted at smallholder farmers engaged in the production of identified commodities across the country, and to actors in other segments of the value chain, in the form of credit guarantee/ risk-sharing and low interest loans. These include the
Commercial Agricultural Credit Scheme, GESS, ABP and NIRSAL. The smallholder aspect of the schemes, such as GESS and ABP are specifically targeted at providing agricultural inputs, such as fertilisers, agrochemicals, seeds, and seedlings. According to the government, the ABP since 2015, has disbursed 200 billion to more than 1.5 million smallholder farmers of 16 different commodities including rice, wheat, maize, cotton, cassava, soybeans, and groundnut. In total, these smallholder farmers cultivate over 1.4 million ha of farmland. The government attributed the over 10 new rice mills that emerged between 2016 and 2019 to the ABP. These schemes have attracted more than US $\$ 1$ billion of private sector investments to the agricultural sector. As of the third quarter of 2018, NIRSAL had facilitated funds in excess of 85.5 billion for various agricultural projects from different sources. Broken down, this translates to the following investments, agricultural inputs: 43.8 billion, mechanisation: 1.7 billion, primary production: 19 billion, and processing: \#20.9 billion (NIRSAL 2020).

These schemes are, however, faced with a number of challenges at the small and medium-scale levels. These include delays in accessing the facilities, inconsistent implementation arising from changes in the preferred tools of particular governments/officials, unremitted loans, supply of low-quality inputs (direct procurement by government), and allegations of fraud. For instance, in 2017, the Cocoa Farmers Association wrote a letter of protest to the President to 'stop the ongoing procurement exercise on cocoa at the federal Ministry of Agriculture with immediate effect,' claiming that 'most of the inputs procured in the past, like jute bags, solo sprayer pumps, fungicides, and insecticides were rejected by the cocoa farmers as a result of (their) low standard, while those farmers that used (some of them) regretted their action because of the negative impact on their cocoa farms' (Vanguard 2018; Egbas 2020; Falaju 2019).

A PWC report on agricultural finance identified crowd funding and technology enabled commodity exchange as two emerging private sector solutions to farmers' challenges in aggregation, storage, and financial inclusion. It noted that organisations such as Binkabi 
and AFEX Commodities Exchange are leading the movement to provide a ready market for both farmers and buyers at the postharvest segment of the value chain (PWC 2018b).

It is difficult for commercial banks to invest in agriculture at the primary production level, which is dominated by smallholder farmers, because farmers have poor book-keeping practices, limited financial skills, and lack collateral. These are three essential requirements for banks to make lending decisions. Most financial institutions have a high interest rate, which can be quite

Table 5.1: Federal government initiatives in agribusiness finance

\begin{tabular}{|c|c|c|c|c|}
\hline Policy name & Year & Govt & Purpose & Govt, party \\
\hline $\begin{array}{l}\text { Nigerian } \\
\text { Incentive-Based } \\
\text { Risk Sharing } \\
\text { for Agricultural } \\
\text { Lending (NIRSAL) }\end{array}$ & 2017 & $F G$ & $\begin{array}{l}\text { US } \$ 500 \text { million non-bank financial institution wholly } \\
\text { owned by CBN. It was established to stimulate the flow } \\
\text { of finance and investment into agricultural sector value } \\
\text { chains. It is designed to redefine, measure, re-price, } \\
\text { and share agribusiness-related credit risk. It specialises } \\
\text { in structuring agricultural value chains from end to end } \\
\text { with technological innovations to present de-risked, } \\
\text { high-return investment environments for global finance. } \\
\text { Four main facilities: US } \$ 300 \text { million risk sharing facility, } \\
\text { US } \$ 60 \text { million technical assistance facility, US } \$ 30 \\
\text { million insurance facility, and US\$10 million rating } \\
\text { facility. }\end{array}$ & APC \\
\hline $\begin{array}{l}\text { Anchor Borrowers } \\
\text { Programme (ABP) }\end{array}$ & 2015-date & $F G$ & $\begin{array}{l}\text { Increase banks' financing to the agricultural sector } \\
\text { through loans targeted at smallholder farmers. Boost } \\
\text { productivity growth through the provision of improved } \\
\text { seedlings, as well as access to finance for rural } \\
\text { farmers in the agricultural sector across } 10 \text { different } \\
\text { commodities, namely: rice, maize, cassava, cocoa, } \\
\text { tomato, cotton, oil-palm, poultry, fish, and livestock/ } \\
\text { dairy. }\end{array}$ & APC \\
\hline $\begin{array}{l}\text { Growth } \\
\text { Enhancement } \\
\text { Support Scheme } \\
\text { (GESS) }\end{array}$ & 2012 & $F G$ & $\begin{array}{l}\text { Subsidise the costs of major agricultural inputs, such } \\
\text { as fertiliser and seedlings for farmers. Target } 5 \text { million } \\
\text { farmers each year for four years, who will receive GESS } \\
\text { directly to their mobile phone. Change the role of } \\
\text { government from direct procurement and distribution } \\
\text { of fertiliser to a facilitator of procurement, regulator of } \\
\text { fertiliser quality, and catalyst of active private sector } \\
\text { participation in the fertiliser value chain. }\end{array}$ & PDP \\
\hline $\begin{array}{l}\text { National } \\
\text { Agricultural } \\
\text { Investment Plan }\end{array}$ & 2011-2014 & $F G$ & $\begin{array}{l}\text { Implement the Maputo Declaration to allocate } 10 \text { per } \\
\text { cent the annual budget to agriculture to achieve } 6 \text { per } \\
\text { cent agricultural growth. }\end{array}$ & PDP \\
\hline $\begin{array}{l}\text { Commercial } \\
\text { Agricultural Credit } \\
\text { Scheme (CACS) }\end{array}$ & 2009 & $F G$ & $\begin{array}{l}\text { CBN introduced the CACS in } 2009 \text { to target commercial } \\
\text { agricultural enterprises with agricultural assets of no less } \\
\text { than } 100 \text { million and plans to increase assets to } 250 \\
\text { million within a period of three years. Non-integrated } \\
\text { farms/agro-enterprises with assets of } \$ 50 \text { million and } \\
\text { plans to grow their assets to } 150 \text { million within three } \\
\text { years could also access CACS. The Scheme included } \\
\text { firms in production, processing, marketing, or supply of } \\
\text { farm inputs, and covered a wide range of agro-products. }\end{array}$ & PDP \\
\hline $\begin{array}{l}\text { Export Expansion } \\
\text { Grant (EEG) }\end{array}$ & 1999 & $F G$ & $\begin{array}{l}\text { To stimulate export-oriented activities in the non-oil } \\
\text { export sector. It was suspended in January } 2014 \text { and } \\
\text { revived in } 2017 . \text { Implemented by the Ministry of Trade. }\end{array}$ & PDP \\
\hline $\begin{array}{l}\text { Export Expansion } \\
\text { Grant (EEG) }\end{array}$ & 1999 & $F G$ & $\begin{array}{l}\text { To stimulate export-oriented activities in the non-oil } \\
\text { export sector. It was suspended in January } 2014 \text { and } \\
\text { revived in } 2017 . \text { Implemented by the Ministry of Trade. }\end{array}$ & PDP \\
\hline
\end{tabular}

Source: Authors' own 
steep for farmers and may discourage many smallholder farmers from applying for credit. Furthermore, smallholder farmers often fail to repay loans for multiple reasons, including farm failures and diversion of loans to other purposes not connected to farming. This failure has been a major programme targeted at smallholder farmers across the country. At the International Agric Expo 2018, held in Kano in October, the Deputy Governor of Kano State, Alhaji Nasiru Yusuf Gawuna, lamented that only four farmers out of 4,500 in Kano were able to repay the loans given to them (Murtala 2018). Under these conditions, even the government can hardly sustain the facilities provided to assist smallholder farmers. Thus, the NIRSAL has had to carry out programmes to educate farmers on the use of credit facilities and the importance of paying loans, as well as organise farmers into cooperatives for the dissemination of information, monitoring, and management. 


\section{DONOR INTERVENTIONS IN THE COCOA AND RICE VALUE CHAINS}

Given the importance of rice in global and national food security, a number of international players have been involved with rice in Nigeria. These range from multilateral institutions like the World Bank, donor nations, rice exporting countries, and Nigeria's West African neighbours with connections to the Nigerian market. There are also various initiatives from regional bodies such as CARD and the Sustainable Rice Platform.

One of the early post-independence major donor and multilateral agency interventions in agriculture in Nigeria is the World Bank's series of Agricultural Development Projects. These projects largely focused on the expansion of arable land, or more effective use of inputs, land irrigation, and supportive infrastructure, along with credit, to increase primary production. As a result of the experience from the World Bank's Agricultural Development Projects, the Fadama project series was introduced, which concluded its third phase with additional funding (AF) in 2019. Fadama I (1993-1999, US\$67.5 million), Fadama II (2004-2006 US\$100 million), and Fadama II+AF (2008-2019, US\$250 million), sought to make agricultural production less dependent on erratic rainfall, raise farmers' incomes, and augment food security by developing small-scale irrigation through the extraction of shallow groundwater with low-cost petrol-driven pumps. The national government and the participating states and local governments usually pay counterpart funds to support these projects. These states and local governments paid US $\$ 200$ million counterpart funding to support Fadama III, which was a project of US\$450 million, involving 35 states and the Federal Capital Territory. The Fadama series was particularly useful for rice production.

The World Bank has a number of intervention projects with direct consequences for rice and cocoa value chains, especially the Commercial Agriculture Development Project (2009-2017). Apart from the World Bank, there are a number of multilateral and bilateral donor arrangements to promote value chain development in cocoa and rice. Some of these include the JICA, the United States International Agency for Development (USAID), the FAO, the International Labour Organization (ILO), the WCF, and the governments of Brazil and Morocco. These bodies have introduced new technologies, promoted mechanisation, facilitated the empowerment of women and youth, and provided technical training on the proper use of inputs, post-harvest processing, storage, and marketing to smallholder farmers in Nigeria. Some of these are summarised in Table 6.1. 
Table 6.1: Some bilateral/multilateral donor initiatives in agriculture

\begin{tabular}{|c|c|c|c|}
\hline $\begin{array}{l}\text { Project/ } \\
\text { programme }\end{array}$ & Year & Description & $\begin{array}{l}\text { Donor/ } \\
\text { partner }\end{array}$ \\
\hline $\begin{array}{l}\text { The Green } \\
\text { Imperative }\end{array}$ & $2020-2030 t$ & $\begin{array}{l}\text { A 10-year, government-to-government programme, under } \\
\text { Brazil's More Food International Program which aims to } \\
\text { create about } 5 \text { million jobs and inject over US } \$ 10 \text { billion into } \\
\text { the Nigerian economy within } 10 \text { years, with an initial US } \$ 1.2 \\
\text { billion fund. The Program also aims to create a sustainable } \\
\text { supply chain of agricultural raw materials for Nigeria's large } \\
\text { manufacturing companies to source locally, thereby saving } \\
\text { billions of US dollars in food-related foreign exchange. The } \\
\text { programme will lead to the reactivation of six motor assembly } \\
\text { plants in the six-geopolitical zones of the country for assembling } \\
\text { tractors and other implements. Completely knocked down parts } \\
\text { for about 5,000 tractors and numerous implements (for local } \\
\text { assembly) will be imported annually for a period of } 10 \text { years. }\end{array}$ & $\begin{array}{l}\text { Government } \\
\text { of Brazil }\end{array}$ \\
\hline $\begin{array}{l}\text { Agro-Processing, } \\
\text { Agricultural } \\
\text { Productivity } \\
\text { Enhancement } \\
\text { and Livelihood } \\
\text { Improvement } \\
\text { Support } \\
\text { (APPEALS) }\end{array}$ & $2017-2023$ & $\begin{array}{l}\text { To enhance the agricultural productivity of small- and medium- } \\
\text { scale farmers and improve value addition along priority value } \\
\text { chains in the participating states: Cross River, Enugu, Kaduna, } \\
\text { Kano, Kogi and Lagos. Sixty thousand farmers are to benefit } \\
\text { from the US\$200 million project, which involved production and } \\
\text { post-harvest management and the empowerment of women } \\
\text { and youth. The aim is to reduce post-harvest losses, facilitate } \\
\text { the consolidation of produce and primary processing by farmers' } \\
\text { cooperative societies and small- and medium-scale enterprises, } \\
\text { and provide infrastructural support to agribusiness clusters. }\end{array}$ & World Bank \\
\hline $\begin{array}{l}\text { Cocoa Livelihood } \\
\text { Programme }\end{array}$ & 2014-2019 & $\begin{array}{l}\text { To provide business skills training and support for the } \\
\text { diversification of rural economies in order to increase cocoa farm } \\
\text { household incomes. The Programme reached 19,553 farmers in } \\
10 \text { Nigerian states (US } \$ 1.2 \text { million). }\end{array}$ & WCF \\
\hline $\begin{array}{l}\text { Youth Employment } \\
\text { in Agriculture } \\
\text { Programme (YEAP) }\end{array}$ & 2012 & $\begin{array}{l}\text { To build capacity, both technical and institutional, for youth } \\
\text { to engage in agriculture profitably. The Federal Ministry of } \\
\text { Agriculture and Rural Development, ILO and FAO collaborated } \\
\text { in } 2012 \text { to design and implement YEAP nationally to address the } \\
\text { issues of youth unemployment, underemployment, and working } \\
\text { poverty in Nigeria. YEAP was piloted in six states: Lagos, Oyo, } \\
\text { Imo, Rivers, Bauchi. }\end{array}$ & FAO/ILO \\
\hline $\begin{array}{l}\text { National Fadama } \\
\text { phase II and III + } \\
\text { AF (phase II was } \\
\text { partly funded } \\
\text { by the African } \\
\text { Development } \\
\text { Bank, US\$30 } \\
\text { million) }\end{array}$ & $\begin{array}{l}1993-1999 \\
2004-2006 \\
2008-2019\end{array}$ & $\begin{array}{l}\text { Expand arable land and promote more effective use of inputs, } \\
\text { land irrigation, and supportive infrastructure, along with the } \\
\text { provision of credit to increase primary production. }\end{array}$ & $\begin{array}{l}\text { World Bank/ } \\
\text { AfDB }\end{array}$ \\
\hline $\begin{array}{l}\text { Rice Post Harvest } \\
\text { Processing and } \\
\text { Marketing Project }\end{array}$ & 2011-2016 & $\begin{array}{l}\text { Improvement in post-harvest processing (parboiling, milling, } \\
\text { and marketing), using false bottom technology for higher quality } \\
\text { parboiled rice and increased profits for small-scale parboilers, } \\
\text { millers, and traders in Nasarawa and Nigeria state, later } \\
\text { extended to } 21 \text { states. }\end{array}$ & JICA \\
\hline $\begin{array}{l}\text { Commercial } \\
\text { Agriculture } \\
\text { Development } \\
\text { Project }\end{array}$ & 2009-2017 & $\begin{array}{l}\text { To strengthen agricultural production systems by facilitating the } \\
\text { adoption of appropriate and existing agricultural technologies } \\
\text { and the building of rural infrastructure, such as roads (network of } \\
\text { farm access roads) and rural energy. } \\
\text { The second component is to facilitate access to markets } \\
\text { for targeted value chains among small- and medium-scale } \\
\text { commercial farmers in the five participating states (Cross River, } \\
\text { Enugu, Kaduna, Kano, and Lagos). The target value chains } \\
\text { included oil palm, cocoa, fruit trees, poultry, aquaculture, and } \\
\text { dairy, with maize and rice as staples. }\end{array}$ & World Bank \\
\hline
\end{tabular}


Nigeria's first COVID-19 case was recorded on 27 February 2020. As of 14 July 2020, of the 33,616 cases that were confirmed, 13,792 cases were discharged, while 754 died. The government imposed a lockdown in Lagos, Ogun, and Abuja from 30 March to 4 May 2020. Many state governments enforced a dusk to dawn curfew on movement and closed down businesses, places of worship, and schools. The situation was eased in May with offices allowed to open for a limited period of time, restaurants were also allowed to open for pick-up and delivery only. Commercial vehicles were to reduce the number of passengers onboard. The inter-state travel ban was lifted in June. In the same month, the chairman of the Presidential Task Force on COVID-19, Boss Mustapha, announced that 60 per cent of the disease was concentrated in 18 of the 774 local governments in the country, with Lagos state alone accounting for 11 of those local governments.

As shown in Figures 7.1 and 7.2, the pandemic has been relatively less severe in Nigeria compared to the experiences in Europe for instance. However, it generated great panic and government took drastic measures in the first two months, which saw the lockdown of states like Lagos, Ogun, and Abuja, the epicentres of the pandemic. Both local and international flights were stopped. The government revised its budget and produced a policy document consisting of a fiscal stimulus support package to support the

Figure 7.1: Timeline of the spread of confirmed cases response in the states and a special intervention fund to the Nigerian Centre for Disease Control. It sought to expand its cash transfer programme and distribute food items in the form of palliatives to citizens in collaboration with the state governments. The government assisted businesses through a directive for a three-month moratorium for all federal government funded loans issued by the Nigerian Export-Import Bank, the Bank of Agriculture and the Bank of Industry. Beyond the cities, labour supply to some farm communities was halted by the lockdown or by rural community leaders, who have refused entry of persons from the cities to avoid spread of the disease to the farms.

As early as 5 May 2020, Bloomberg reported that health protocols introduced by Nigerian authorities to curb the spread of the COVID-19 disease had delayed cocoa exports, leaving at least 30,000t stranded at the Lagos port and in warehouses. Farmers in many parts of the country's southern cocoa growing belt were unable to move their produce to the ports due to restrictions on movement imposed by the authorities, leaving more shipments stuck in warehouses or on the way to the port (Awere 2020). Aref-Adib and Martin (2020) also noted that the demand for Nigerian cocoa is considered to be at risk of decline because Europe, a major epicentre of the COVID-19 pandemic is the export destination of about 81 per cent of Nigerian cocoa bean.

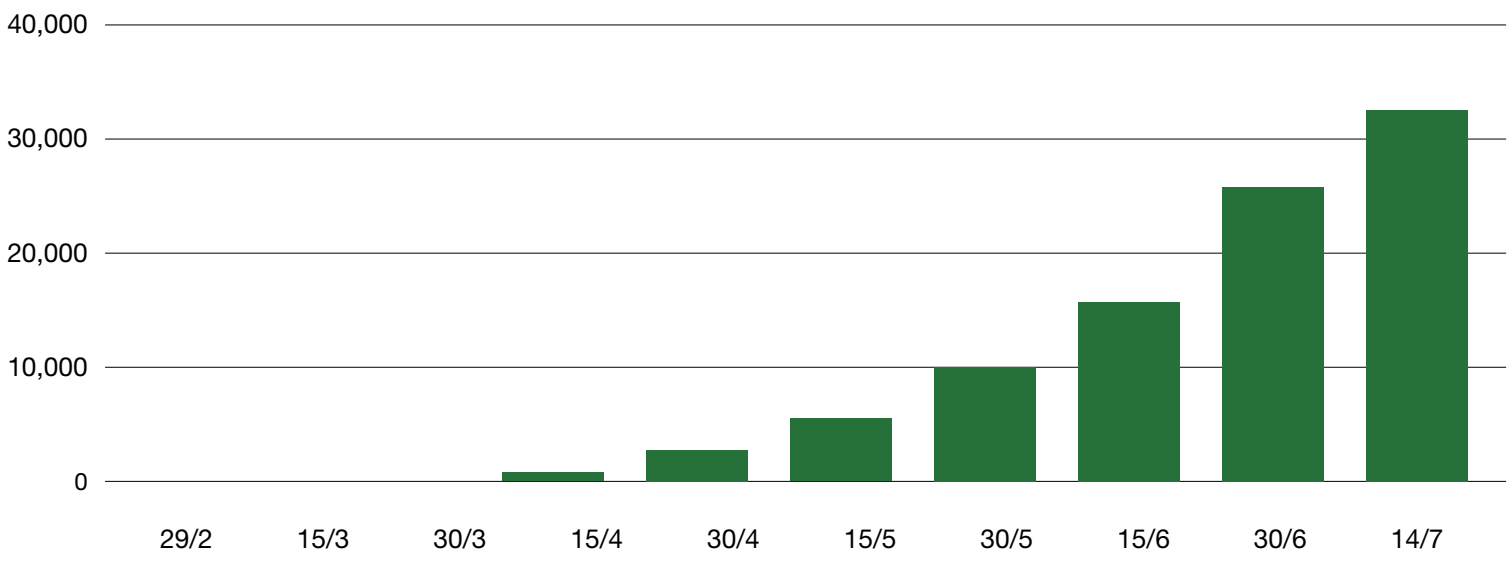

Day/month (2020)

Source: NCDC data (2020) 
Figure 7.2: Timeline of spread of cases across 36 states

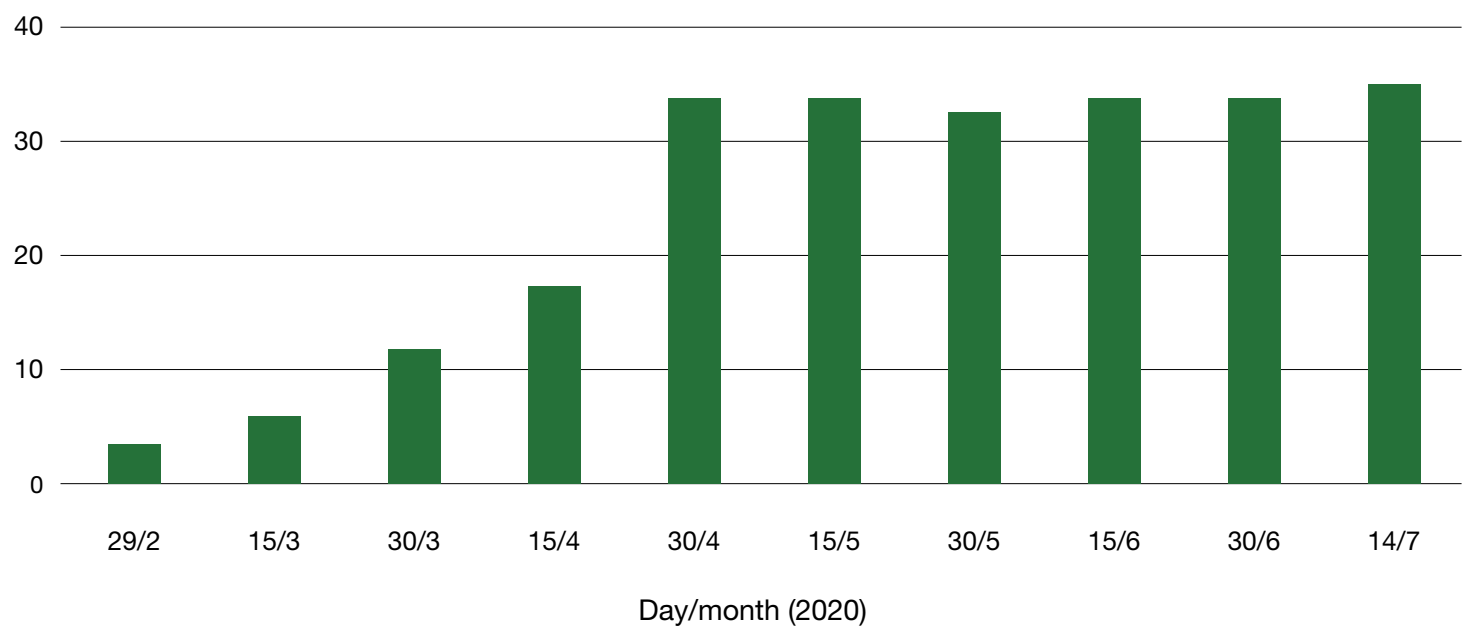

Source: NCDC data (2020)

Figure 7.3: Percentage of deaths per number of cases

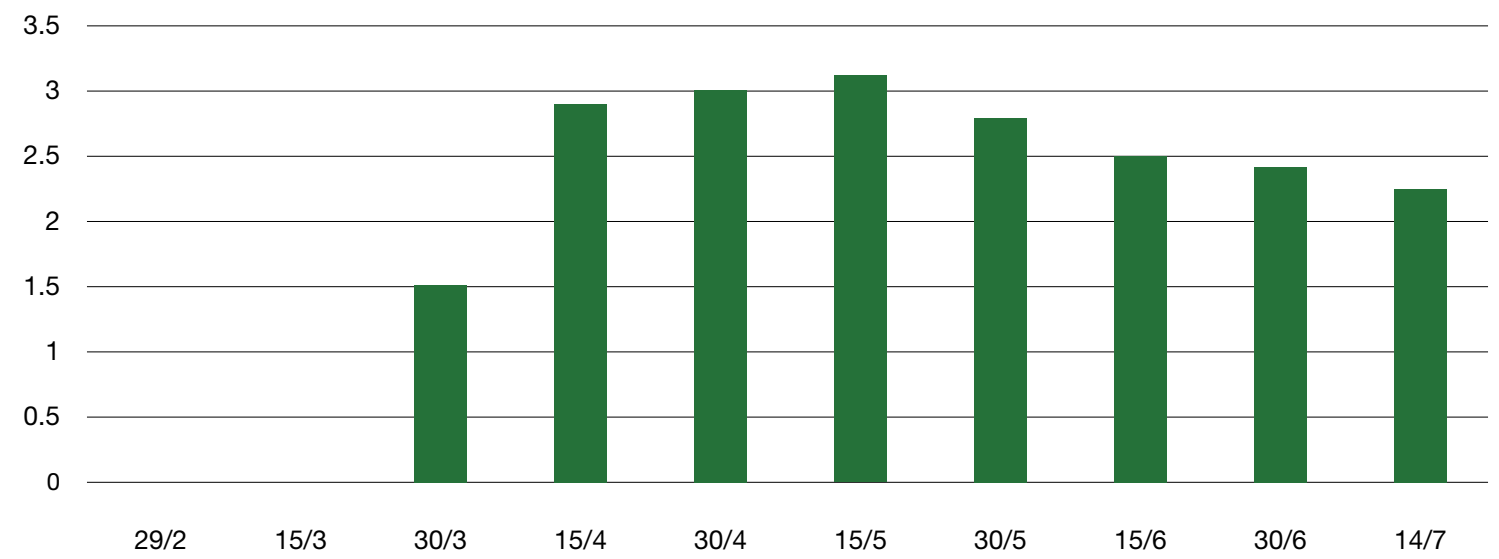

Day/month (2020)

Source: NCDC data (2020)

The ban on interstate movement and the fear of the spread of the disease has also affected the supply of agricultural inputs. Fertilisers, agro-chemicals, and seedling supply has suffered as a result of increases in transportation fares and other difficulties, including harassment by security personnel on the road. The lockdown coincided with the planting seasons for both rice and cocoa, adversely affecting planting activities, including access to tractors and extension services. Public sector workers were asked to stay at home for months. However, a number of millers of rice reported increased business activities and profits resulting from requests from government, who purchased rice for distribution as palliatives to citizens during the lockdown. Furthermore, the general effects of the COVID-19 pandemic varied from state to state because there was a variation in policy responses across the states. Many of the states never shut down, although the federal government's ban on inter-state travel affected all. 


\section{Political settlement and the policy thrust in agricultural commercialisation}

There is certainly a consensus on agricultural commercialisation in Nigeria, that is traceable to the adoption of SAP in the 1980s. This is symbolised by the abolition of marketing boards for cocoa. Pressures for foreign exchange and the need for food security have ensured that a policy of commercialised agriculture is sustained over the years. However, this policy of preference for agricultural commercialisation has been mediated by a concern and commitment to ensuring food security in a country with high levels of poverty and malnutrition. The goal of food security seems to have placed rice above cocoa in terms of government intervention to support primary production in these value chains. Thus, it can be argued that while there is a political settlement among policy makers in support for agricultural commercialisation, bottom-up pressures have required the national government to focus more of its power and resources in the rice value chain than in the cocoa value chain.

After a series of piecemeal policies in agricultural commercialisation, which began with structural adjustment in 1986, the ATA was a major step towards the rediscovery of agriculture as a commercial enterprise, in so far as rice production is concerned. Rice was part of the target list of staple foods with a huge gap between consumption and production, which was covered through imports. Rice in particular was targeted, partly because it is grown more widely across the states of the federation, and partly because, compared to other grains, it requires less inputs in terms of fertiliser and agro-chemicals and can be grown all year round with minimal irrigation technology. This was demonstrated during the series of Fadama projects. Besides, it is a chain that can be conceived as entirely domestic, from production to the market or for consumption. The focus is to make the country self-sufficient by substituting domestic rice production for imports as a national staple food. Although the higher quality of rice that comes from the industrial millers may not be price competitive relative to imports from Thailand, the lesser quality of rice coming from the cottage or small-scale millers service the demands of poorer segments of society, especially in the rural areas. That is why they continue to thrive regardless of the measures required to secure the market. These cottage and small-scale millers can be helped by mechanisation.

A high level of attention to the cocoa value chain has not been sustained consistently over time in national policy making because of the regional catchment of the tree crop. Cocoa is predominantly grown in the cocoa belt in the South West and South South regions, with Ondo state in the South West and Cross River state in the South South being the current leading growers. This is contrary to rice, which is grown in virtually all states of the country. It is therefore no coincidence that national governments under the leadership of southern presidents have paid more attention to cocoa than those of the north, even though cocoa remains the major non-oil source of foreign exchange for the country. After a lull in activism in the cocoa value chain since 2015, the major move of President Buhari's government was the 2018 International Summit on Cocoa, which was to culminate in a 10-year plan for cocoa, and his assenting to the 2010 International Cocoa Agreement. Although the Buhari government occasionally expresses commitment to promoting cocoa, it has not buttressed this commitment with the kind of campaign witnessed under President Obasanjo (1999-2007) and Goodluck Jonathan (2010-2015). Under Obasanjo, cocoa intervention was directly under the purview of the presidency, while President Jonathan appointed Dr Adesina as Minister for Agriculture as explained earlier.

The relative capacity of the government to effectively intervene to uphold public policy without negative repercussions at the international level is also important. Additionally, the relative financial and technological capacity or incapacity of domestic players to break into a very sophisticated market at the midstream and downstream segments has impacted the commercialisation of the cocoa value chain. Crystallising a political settlement seems to be more difficult across the cocoa value chain because of the global structure of the value chain. In the case of rice, a policy of import substitution seems easier to pursue, 
since it involves intervening through control of access to the domestic market. In contrast, the government is largely unable to increase access to the competitive global market for cocoa bean and cocoa butter. The huge investment required and the uncertainties of the international market further disadvantage cocoa processors' access to finance from the banks. Pressures for a return to cocoa marketing boards appear too radical in contrast with the general policy thrust for private sector led growth and the primacy of market forces, hence the preference for a CCN that is run by the private sector. Reintroducing the marketing boards would amount to reregulating a liberalised cocoa market. This is further complicated by the conflicting policies of export promotion in general and the desire to encourage local value addition before export. Besides, there has been limited experience and idea sharing across the state level governments that could advance the commercialisation process throughout the country and across the value chains.

Further still, rice is an annual crop with two harvests a year. It can be grown in most parts of the country, especially with irrigation. Thus, rice farmers only require short-term land use contracts. It is here that a major difference occurs in terms of access to farmland between cocoa and rice producers. Due to the long gestation period before the first harvest, cocoa requires a longer-term contract with the risks that come with it in terms of disease and climate change, across the life span of the cocoa trees. In cocoa cultivation, one encounters the full multiple and complex land tenure system in operation in Nigerian communities. Efforts to review the land use act since the 1970s have not succeeded. The situation is such that experimentation is easier in rice cultivation than cocoa, whether it is in terms of public partnerships or out grower schemes, for instance. Out grower schemes have become the norm in rice production, benefiting the goal of increased production and local processing by large companies. We have seen the easy entrance into rice processing by state governments and the many private out grower schemes across the country in rice production and processing. This has not been the case with cocoa. In 2020, the first out grower scheme in cocoa was initiated by Cross River state. It will take at least five years before the state is able to assess the success of this experiment in cocoa production and processing.

There has been a noted increase in rice production in the last decade, owing largely to government incentives at both the national and state government levels. Many of the large companies that were previously major importers of rice into the country have transited into rice production and processing, introducing a number of initiatives with the Olam nucleus farm and out grower model being the flagship model. Increasingly, state governments have seen the ever-growing demand for rice as an opportunity for revenue and have entered into a number of intergovernmental and public private partnerships in rice production, processing, and marketing. For the industrial millers, import bans or quotas safeguard the urban markets, which show a preference for the parboiled rice coming from Asia. Thus, as far as agricultural commercialisation is concerned, the rice sector is likely to thrive. Consecutive governments have demonstrated commitment to local rice production because of the priorities given to staple foods as essential elements of food security in a society that has become the poverty capital of the world since 2018.

However, due to Nigeria's low input farming practices and inadequate or poor use of fertilisers and other agrochemicals, productivity remains low. It is estimated that there are 45,000 tractors in the country. This translates into a density of 5.7 tractors per $100 \mathrm{~km}^{2}$, far short of what is required to improve production in rice and other staples (Oxfam 2019). It is hoped that the sustained commitment of the federal government, partnerships with donors, including the governments of Brazil and Morocco, and the increasing interest of state governments and large-scale businesses, will drive gains in mechanisation, local production, and the use of fertiliser. As a result, Nigeria will see an increase in paddy production and quality rice processing that will be price competitive globally.

Another important factor in the commercialisation process is the relative efficiency of the public bureaucracy. Government interventions to support the commercialisation process, whether in terms of financial risk sharing or the distribution of inputs, have been accused of corruption. The consistent and timely provision of quality inputs, fertilisers, chemicals, and seeds and seedlings is important. The inefficiencies of government, at both national and state levels, are important factors that have hindered cocoa value chain's commercialisation. Thus, government intervention has not been consistently forthcoming and when it has, it has been ineffective.

Further, production and commercialisation of rice has been encouraged by rapidly growing urban markets, attracting medium and large-scale farmers to grow the crop alongside smallholders. However, incentives for production and commercialisation have been undermined, in part, by unpredictable competition from smuggled imports. Interestingly, governments at both national and state levels have provided incentives 
to powerful importers, who could have circumvented formal rules on importation, such that they have invested in direct cultivation and engaged in out grower programmes. Thus, although Nigeria has not achieved the target of 12.85 million $t$ of rice by 2018 , stated in the NRDS, the rice value chain is looking up and is being led by large-scale investors carrying smallholders along.

The cocoa value chain is essentially global. While local smallholder farmers are the main players at the upstream segments of the value chain, they face limited capacity to benefit from the increasing global demand for cocoa products, especially chocolate as a result of poor profit transmission. Smallholder farmers find it difficult to thrive and increasingly face poverty. They are also victims of government inefficiencies. The domestic actors in the midstream do not have the clout in term of capital and know-how to compete globally.

Given the relative dominance of large multinational companies in the downstream segment of the cocoa value chain, there has been a demonstrated preference among domestic actors to encourage local processing and to grow the local market for cocoa products. Thus, government must promote local grinding and the processing of a variety of finished cocoa products for value addition, and encourage local consumption of cocoa products simultaneously. Unlike rice, which is a staple, cocoa products cannot command a large market in an economy with a very large population of poor people. It is difficult for the government to create the local market for cocoa production. It simply lacks control over the consumption end of the chain.

Nonetheless, the government cannot abandon cocoa because certain events have tended to revive interest in promoting cocoa production and export. The first is the dwindling foreign revenue from crude oil (the major source of rent), which has pressured successive governments to diversify the economy. Dwindling oil revenue has arisen from events in the volatile oil market, as experienced in the economic crisis and structural adjustment of the 1980s and 1990s, the agitation and rise of militancy in the Niger Delta oil bearing communities, which has adversely affected oil production in that region, and a series of economic recessions in 2008-2009 and 2016-2017, largely owing to the fall in the price of oil in the international market.

For the future of cocoa farming to thrive in Nigeria requires intervention by the government and the enforcement of sustainable cocoa initiatives by TNCs. These initiatives should aim to encourage farmers to discard old production practices and embrace new technology, inspire younger generations into cocoa enterprises, and drive local cocoa value addition. This can be achieved by providing the needed infrastructure and financial incentives to participate in the downstream and midstream segments of the cocoa value chain as a long-term government programme.

\section{The role of donors}

Traditional development partners have engaged actively with the value chains over the past decades. A review of the thrust of these interventions shows that they have been designed to stimulate commercialisation and to facilitate the participation of smallholder farmers in the resulting commercialised processes. The mainstreaming of gender and climate change issues has helped to sensitise policy makers to pay attention these issues (Agbonkhese 2018).

\section{Social differences within the value}

\section{chains}

Commercialisation has not equally benefited women farmers because of historic division of labour, relative access to land, and the dominance of male farmers in agricultural policy making and farmers' associations. As a result, Nigeria has witnessed an increase in the number of women farmers' associations to focus on women farmers' issues and to project women voices in decision making regarding agricultural commercialisation. In many traditional land tenure systems women lack access to and control over land. The lack of access is often greater in the cocoa belt because of the long lifespan of the cocoa tree, and landowners' unwillingness to provide long-term contracts required for cocoa farming.

Access to land for the cultivation of rice is easier than cocoa. However, there is a clear gender gap in land ownership and access because of the patriarchal culture in many communities. The cultural limits that only allow married women to interact with men in some parts of northern Nigeria have disadvantaged women from accessing extension services. Rural infrastructural deficits that require farmers to walk long distances expose women to intimidation and sexual harassment.

The cocoa boom, which occurred immediately after the dissolution of the marketing boards, did not last. As a result, the power gained by cocoa labourers due to the increase in demand for labour was quickly lost to the unemployment that followed the end of the boom. Structural adjustment has meant the weakening of labour unions and de-unionisation of many private firms. Most processing firms have no workers' unions to advance the interest of labourers. 


\section{value chains}

The COVID-19 pandemic and the government's response has had mixed consequences on the rice and cocoa value chains in Nigeria, some of these are still unfolding. For rice, the lockdown and fear of the pandemic has been the major challenge, while the increasing demand for food and government desire for palliatives have benefited producers and processors. The cocoa value chain has been affected by the shrinking export market in Europe and other importing countries, which are currently experiencing lockdowns. The lockdown has created modest logistic problems for local input supplies and farm labour. Although governments have provided exceptions to the movement of agricultural produce, enforcement has been difficult. 


\section{ENDNOTES}

1 Similar documents were produced for the lower levels of government. State Economic Empowerment and Development Strategy (SEEDS) at the state government level and Local Economic Empowerment and Development Strategy (LEEDS) at the local government level.

2 In August 2019, while playing host to his political party (APC) governors' for Eid-el-Kabir lunch at his country home in Daura, President Buhari directed the CBN not to provide foreign exchange for the importation of food, saying his administration had achieved food security. He noted that some states like Kebbi, Ogun, Lagos, Jigawa, Ebonyi, and Kano had already taken advantage of the federal government's policy on agriculture with huge returns in rice farming. https://www.premiumtimesng. com/news/headlines/346473-buhari-to-cbn-weve-achieved-food-security-no-forex-for-foodimportation.html (accessed 12 October 2020).

3 Both Obasanjo and Adesina are from the cocoa belt of south western Nigeria. Obasanjo is a framer from Ogun state, while Adesina is an agricultural economist, whose father was a farmer from Oyo state. One interview noted that when they returned to their towns in the region, they would usually be confronted by farmers and traditional rulers about the conditions of the cocoa farms, a traditional source of wealth since the 1950s. 
Abayomi, W. (2019) 'Resumption of the Export Expansion Grant Scheme: Administration and Challenges', KPMG Insights, 16 September, https://home.kpmg/ng/en/home/insights/2019/09/resumption-of-the-export-expansiongrant-scheme--administration-0.html (accessed 20 September 2020)

Adebayo, K.; Babu, S. C.; Sanusi, R. and Sofola, M. (2015) 'Private Sector Participation in Agricultural Extension for Cocoa Farming in Nigeria: The Case of Multi-Trex Integrated Foods', Knowledge Driven Development 141-162

ActionAid (2020) Community Participatory Assessment of Government Expenditure on Agriculture/Community Scorecards on Smallholder Women Farmers Access to Agricultural Insurance Services in Nigeria, Abuja: ActionAid Nigeria

Adebayo, T-H. (2019) 'Nigeria's Border Policy Leaves Concerns About Rice Shortage', Premium Times, 6 October, https://www.premiumtimesng.com/news/headlines/356224-nigerias-border-policy-leaves-concerns-about-riceshortage.html (accessed 12 May 2020)

Adefeko, A. (2018) 'Cocoa Production and Processing in Nigeria: Need for a Stimulus', The Cable, 13 February, https://www.thecable.ng/cocoa-production-processing-nigeria-need-stimulus (accessed 12 June 2020)

Aderinto, S. (2013) 'Where is the Boundary? Cocoa Conflict, Land tenure, and Politics in Western Nigeria, 1890s1960', Journal of Social History 47(1): 179-195

Adesina, A. (2013a) 'The Opportunity in Nigeria's Cocoa Sector', special address to the World Cocoa Foundation, Washington, DC, 5 June, https://www.worldcocoafoundation.org/wp-content/uploads/Minister-AdisinasRemarks-DC-PM-20132.pdf (accessed 12 May 2020)

Adesina, A. (2013b) 'Transforming Nigeria's Agriculture', speech delivered at the inauguration of the Agriculture and Food Security Center of the Earth Institute of Columbia University, New York, 10 September, http://agriculture. columbia.edu/events/past-events/inaugural-seminar-the-nexus-of-agriculture-environment-and-livelihoods/ transforming-nigerias-agriculture/ (accessed 12 May 2020)

Adeyemi, K. (2020) '126 Workers Locked for Months in Rice Factory Rescued', The Nation, 23 June, https:// thenationonlineng.net/126-workers-locked-for-months-in-rice-factory-rescued/ (accessed 8 January 2020)

Adeyemo, I. (2018) 'Nigeria's Population Now 198 Million NPC', Premium Times, 12 April, https://www.premiumtimesng. com/news/top-news/264781-nigerias-population-now-198-million-npc.html (accessed 8 April 2020)

AfDB/OECD/UNDP (2014), African Economic Outlook 2014: Global Value Chains and Africa's Industrialisation, Paris: OECD Publishing, https://doi.org/10.1787/aeo-2014-en (accessed 6 April 2020)

Afolabi, M.M. (2015) 'Commercialisation of Agriculture in Nigeria: Gender Analysis of Cash crop Production in Yekemi Osun State', PhD thesis, University of Hull

Agbonkhese, J. (2018) 'What Women farmers Suffer cultivating the Foods Nigerians Eat Daily', Vanguard, 25 January, https://www.vanguardngr.com/2018/01/women-farmers-suffer-cultivating-foods-nigerians-eat-daily/ (accessed 6 November 2020) 
Agboola, S. A. (1979) An Agricultural Atlas of Nigeria, Oxford: Oxford University Press

Aiyede, E. R. and Igbafe A. A., (2018) 'Institutions, Neopatrimonial Politics and Democratic Development in Africa' in T. Falola and S. Oloruntoba (eds.), Palgrave Handbook of African Politics, Democracy and Development, New York: Palgrave Macmillan

Akinyemi, F. O. (2013) 'An Assessment of Land-Use Change in the Cocoa Belt of South-West Nigeria', International Journal of Remote Sensing 34(8): 2858-2875

Aref-Adib, M. and Martin, S. (2020) Economic Impact of and Policy Responses to the corona virus pandemic: early evidence from Nigeria, London: ODI Publications, https://set.odi.org/wp-content/uploads/2020/04/ Economic-impacts-of-and-policy-responses-to-the-coronavirus-pandemic-early-evidence-from-Nigeria-2.pdf (accessed 6 June 2020)

Aromolaran, A.; Muyanga, M.; Jayne, T. and Oyebade, J. (2020) 'Shaking off Decades of Stagnation in Nigerian Cocoa Sector', APRA blog, February 6, https://www.future-agricultures.org/blog/shaking-off-decades-ofstagnation-in-the-nigeria-cocoa-sector/ (accessed 4 April 2020)

Avis, W. (2019) 'Urban Expansion in Nigeria, K4D Helpdesk Report 692, Brighton: Institute of Development Studies

Awere, T. (2020) 'Nigeria Cocoa Exports Stalled over Covid-19 Safety Protocols', Bloomberg, 5 May, https:// www.bloomberg.com/news/articles/2020-05-05/nigeria-cocoa-exports-stalled-over-covid-19-safety-protocols (accessed 5 October 2020

Ayetoto, T. (2018) 'Nigeria Will Rake in More Income from Cocoa Market When Consumption Trend Changes Locally', Business a.m., November 27, https://www.businessamlive.com/nigeria-will-rake-in-more-income-fromcocoa-market-when-consumption-trend-changes-locally/ (accessed 22 June 2020)

Badiru, I. O. and Akande, T. I. (2017) 'Assessing the Success of "Cocoa na Chocolate" Musical Intervention in Mobilizing the Youth for Agriculture in Oyo State, Southwestern Nigeria', Journal of Agricultural and Food Information 19(1): 55-65

Bamidele, F.S., Abayomi, O.O. and Esther, O.A. (2010), 'Economic analysis of rice consumption patterns in Nigeria', Journal of Agricultural Science and Technology, 12(1): 1-11

Bello, T. and Mitchell, M.I. (2018) 'The Political Economy of Cocoa in Nigeria: History of Conflict and Cooperation', Africa Today 64(3): 70-91

Berry, S. (1985) Fathers Work for Their Sons, Berkeley: University of California Press

Cadoni, P. (2013) Analysis of Incentives and Disincentives for Cocoa in Nigeria. Technical notes series, MAFAP, FAO, Rome.

Demont, M. and Ndour M. (2015) 'Upgrading Rice Value Chains: Experimental Evidence from 11 African Markets', Global Food Security 5: 70-76

DFID (2010) Building Peaceful States and Societies, A DFID Practice Paper, London: DFID, http://www.gsdrc.org/ docs/open/con75.pdf (accessed 8 August 2020)

ECOWAS (2018) Rice Factbook, Johannesburg: Grow Africa

Egbas, J. (2020) 'Accused of Stealing N75 Billion, Boss of CBN's NIRSAL Opens Up to Pulse', The Pulse, 10 May, https://www.pulse.ng/news/local/accused-of-n75-billion-theft-boss-of-cbns-nirsal-opens-up-to-pulse/ e7147dq (accessed 22 November 2020) 
Egboboh, C. (2020) 'Olam Set to Deepen Local Rice Production to Curb Post COVID-19 food crisis', Business Day, 8 June, https://businessday.ng/companies/article/olam-set-to-deepen-local-rice-production-to-curb-postcovid-19-food-crisis/ (accessed 5 January 2021)

Eze, J. (2019) 'Revisiting the Export Expansion Grant', This Day, 7 May, https://www.thisdaylive.com/index. php/2019/05/07/revisiting-the-export-expansion-grant/ (accessed 19 May 2020)

Falaju, J. (2020) 'FG Inaugurates Committee to Revitalise Extension Services', The Guardian, 21 May, https://guardian.ng/business-services/fg-inaugurates-committee-to-revitalise-extension-services/ (accessed 27 August 2020)

Falaju, J. (2019) 'Why farmers are yet to access FG's N15.68b for farm input since 2017', The Guardian, 6 October, https://guardian.ng/news/why-farmers-are-yet-to-access-fgs-n15-68b-for-farm-input-since-2017/ (accessed 12 June 2020)

FMARD (2016) Agriculture Promotion Policy 2016-2020. Abuja: Federal Ministry of Agriculture and Rural Development

FMARD (2011) Agricultural Transformation Agenda: We Will Grow Nigeria's Agricultural Sector, Abuja: Federal Ministry of Agriculture and Rural Development

FMARD (2010) Agriculture Investment Plan 2011-2014, Abuja: Federal Ministry of Agriculture and Rural Development

Folarin, S. (2020) 'Imota Rice Mill 80\% Completed, says Govt.', Punch, 1 June

https://punchng.com/imota-rice-mill-80-completed-says-govt/ (accessed 6 November 2020)

Fold, N. (2002) 'Lead Firms and Competition in 'Bi-polar' Commodity Chains: Grinders and Branders in the Global Cocoa-Chocolate Industry', Journal for Agricultural Change 2(2): 228-247

FRN (2020) Bouncing Back: Nigeria Economic Sustainability Plan, Abuja: Federal Republic of Nigeria

FRN (2009) National Rice Development Strategy, Abuja: Federal Republic of Nigeria

Gayi, S. and Tsowou, K. (2016). Cocoa Industry: Integrating small farmers into the Global Value Chain, New York and Geneva: United Nations, https://unctad.org/en/PublicationsLibrary/suc2015d4_en.pdf (accessed 20 March 2020)

Godwin, A.C. (2017) 'Nigeria Will Continue to export yam - Audu Ogbe', Daily Post, 27 October, https://dailypost. ng/2017/10/27/nigeria-will-continue-export-yam-audu-ogbeh/ (accessed 15 October 2020)

Gray, H. (2018) Turbulence and Order in Economic Development: Institutions and Economic Transformation in Tanzania and Vietnam, Oxford: Oxford University Press

Gray, H. and Whitfield, L. (2014) Reframing African Political Economy: Clientelism, Rents and Accumulation as Drivers of Capitalist Transformation, LSE Working Paper Series 159, London: London School of Economics

Ibirogba, F. (2018) '84,000 Lose Jobs as 16 Cocoa Companies Go Under', The Guardian, 8 October, https:// guardian.ng/features/84000-lose-jobs-as-16-cocoa-companies-go-under/ (accessed 9 October 2020)

Johnson, M. E. and Ajibola, A. (2016) 'Postharvest Processing, Marketing and Competitiveness of Domestic Rice' in K. Gyimah-Brempong, M. E. Johnson and H. Takeshima (eds.), The Nigerian Rice Economy: Policy options for Transforming Production, Marketing, and Trade. Washington, DC: International Food Policy Research Institute (IFPRI), http://ebrary.ifpri.org/cdm/ref/collection/p15738coll2/id/130481 (accessed 9 October 2020)

Kalejaiye, P.O. (2014) 'The Rise of Casual Work in Nigeria: Who Loses, Who Benefits?' African Research Review, 8(1): 156-176 
Kelsall, T. (2016) Thinking and Working with Political, ODI Briefing, London: ODI Publications, https://www.odi.org/ sites/odi.org.uk/files/odi-assets/publications-opinion-files/10185.pdf (accessed 21 December 2020)

Khan, M. (2010) 'Political Settlements and the Governance of Growth-Enhancing Institutions', London: School of Oriental and African Studies, University of London

Khan, M. (2017) 'Introduction: Political Settlements and the Analysis of Institutions', African Affairs 1(20):1-19

KPMG (2019) Rice Industry Review, Lagos: KPMG Advisory Services, https://assets.kpmg/content/dam/kpmg/ ng/pdf/audit/rice-industry-review.pdf (accessed 27 May 2020)

Kwabena, G.B. (2016) 'Rice in the Nigerian Economy and Agricultural Policies' in K. Gyimah-Brempong, M. Johnson and H. Takeshima (eds.), The Nigerian Rice Economy: Policy Options for Transforming Production, Marketing, and Trade, Washington, DC: International Food Policy Research Institute, http://ebrary.ifpri.org/cdm/ ref/collection/p15738coll2/id/130481 (accessed 8 June 2020)

Laws, E. and Leftwich, A. (2014) Political Settlements, Concept Brief 1, Birmingham: Development Leadership Programme

Leavy, J. and Poulton, C. (2007) Commercialisations in Agriculture, FAC Working Paper 003, Brighton: Future Agricultures Consortium https://opendocs.ids.ac.uk/opendocs/bitstream/handle/20.500.12413/2345/FAC_ Working_Paper_003.pdf?sequenc\%2520e=1

Manley, G. (2017) 'Scaling and Transforming Olam Cocoa to Spur Growth', Olam Insights 1: 1-3, https://www. olamgroup.com/content/dam/olamgroup/files/uploads/IRfiles/Olam-Insights-Cocoa-2017-Issue-1.pdf (accessed 8 April 2020)

MCF (2013) Cocoa Prices and Income of Farmers, Berlin: Make Chocolate Fair! https://makechocolatefair.org/ issues/cocoa-prices-and-income-farmers-0 (accessed 7 March 2020)

Mkandawire, T., (2015) 'Neopatrimonialism and the Political Economy of Economic Performance in Africa: Critical Reflections', World Politics, 67(03): 563-612

Murtala, A. (2018) 'Kano Govt Laments Failure of Farmers to Repay Loans', Vanguard, 13 October, https://www. vanguardngr.com/2018/10/kano-govt-laments-failure-of-farmers-to-repay-loans/ (accessed 25 September 2020)

Muyanga, M. et al. (2019) Changing Farm Structure and Agricultural Commercialisation in Nigeria, APRA Working Paper 26, Brighton: Future Agricultures Consortium

NCDC (2020) Nigeria Centre for Disease Control Covid-19 Nigeria data, https://covid19.ncdc.gov.ng (accessed 05 August 2020)

NEPC (2020) Promising Markets Cocoa Beans, Abuja: Nigerian Export Promotion Council, https://nepc.gov.ng/ cms/wp-content/uploads/2018/06/Cocoa-beans-Promising-markets-Nigeria.pdfl (accessed 10 March 2020)

NPC (2009) NIGERIA Vision 20:2020, Economic Transformation Blueprint, Abuja: National Planning Commission

NIRSAL (2020) CBN LDR's Policy a Major Boost for Agric Finance, Newsletter, Issue 1, February, Abuja: Nigeria Incentive-Based Risk Sharing System for Agricultural Lending

Nwachukwu, I. N. et al. (2008) Evaluation of Second National Fadama Development Project in Nigeria: A Rapid Policy Appraisal, Munich Personal RePEc Archive Paper No. 12914, https://mpra.ub.uni-muenchen.de/12914/1/ MPRA_paper_12914.pdf (accessed 21 May 2020) 
Nwafor, M.; Diao, X. and Alpuerto, V. (2010) A 2006 Social Accounting Matrix for Nigeria: Methodology and results, NSSP Report 7, Washington, DC: International Food Policy Research Institute (IFPRI). http://ebrary.ifpri. org/cdm/ref/collection/p15738coll2/id/127514 (accessed 10 April 2020)

Nwokoye, A. (2019) Building Alliances and Changing Policies: Women Farmers in Nigeria Respond to the Climate Crisis, Interview by Perspective Magazine, Abuja: Heinrich-Böll-Stiftung, https://ng.boell.org/en/2019/12/13/buildingalliances-and-changing-policies-women-farmers-nigeria-respond-climate-crisis (accessed 6 January 2020)

Odukoya, A. O. (2020) Political Economy of Agricultural Commercialisation in Nigeria, APRA Working Paper 29, Brighton: Future Agricultures Consortium

Ogunbiyi, O. M. (2011) 'Assessment of Postharvest Handling and Quality Control Practices of Rice in North Central Nigeria: a Case Study of Lafia, Nasarawa State', Journal of Developments in Sustainable Agriculture, 6(2): 143-163

Okojie, J. (2019) ‘Growing Nigeria's Chocolate for Global Market’, Business Day, 22 May, https://businessday.ng/ agriculture/article/growing-nigerias-chocolate-for-global-market/ (accessed 7 June 2020)

Okpiaifo, G. et al. (2020) 'Consumer's Preferences for Sustainable Rice Practices in Nigeria', Global Food Security 24(100345): 1-11

Okon, A. (2017) 'Cocoa Processors Groan Under N50bn Debt, Huge Losses', The Punch, 27 August, https:// punchng.com/cocoa-processors-groan-under-n50bn-debt-huge-losses/ (accessed 9 May 2020)

Olamola, A. S. and Nwafor, M. (2018) Agriculture Sector Performance Review, Background Report for the Nigeria 2017 Agriculture Joint Sector Review, https:/fscluster.org/sites/default/files/documents/nigeria_agric_sector_ review_report_august_2018.pdf (accessed 26 December 2020)

Oluwole, J. (2017) 'Cocoa farmers Write Buhari, Accuse Agric Ministry of Distributing Fake Fungicides, Pesticides', Premium Times, 28 November https://www.premiumtimesng.com/regional/ssouth-west/250846\%E2\%80\%8Ecocoa-farmers-write-buhari-accuse-agric-ministry-distributing-fake-fungicides-pesticides.html (accessed 7 August 2020)

Onwuamaeze, D. and Uba, C. (2019) ‘Dangote: Nigeria Will Soon Be Exporting Rice', This Day, 6 November, https:// www.thisdaylive.com/index.php/2019/11/06/dangote-nigeria-will-soon-be-exporting-rice/ (accessed 16 June 2020)

Onyekwena, C. (2016) Case study of Olam Outgrower Scheme in Rukubi Rice Farming Communities, Nasarawa State Nigeria, report prepared for the SRAI 2 Project implemented by Michigan State University in Partnership with the Syngenta Foundation for Sustainable Agriculture, https://ageconsearch.umn.edu/record/245894? In=en (accessed 18 June 2020)

Oyakhilomen, C.; Omadachi U.O., and Zibah, R.G. (2012) 'Cocoa Production Agricultural Credit Guarantee Scheme Fund Nexus in Nigeria: A Co-Integration Approach', Russian Journal of Agricultural and Socio-Economic Sciences 9(9): 28-32

Oxfam Nigeria (2019) Agriculture Budget Trend analysis, Abuja: Oxfam, https://nigeria.oxfam.org/agriculturebudget-trends-analysis (accessed 22 September 2020)

Poulton, C. and Chinsinga, B. (2018) The Political Economy of Agricultural Commercialisation in Africa, APRA Working Paper 16, Brighton: Future Agricultures Consortium

PWC (2018a) Boosting Rice Production Through Increased Mechanisation, Lagos: Price Waterhouse Coopers, https://www.pwc.com/ng/en/assets/pdf/boosting-rice-production.pdf (accessed 18 March 2020)

PWC (2018b) Evaluating Agriculture Finance in Nigeria: Towards the US1 Trillion African Food Market 2030, Lagos: Price Waterhouse Coopers, https:/www.pwc.com/ng/en/assets/pdf/evaluating-agric-finance-nigeria.pdf (accessed 7 March 2020) 
PWC (2017) Transforming Nigeria's Agricultural Value Chains: A Case Study of the Cocoa and Dairy Industries, Lagos: Price Waterhouse Coopers, https://www.pwc.com/ng/en/assets/pdf/transforming-nigeria-s-agric-valuechain.pdf (accessed 7 March 2020)

Terazono, E. (2014) 'Welcome to the World of Big Chocolate: Three Companies Will Dominate Processing Sector', Financial Times, 18 December, https://www.ft.com/content/80e196cc-8538-11e4-ab4e-00144feabdc0 (accessed 7 March 2020)

Terdoo, F. and Feola, G. (2016) 'The Vulnerability of Rice Value Chains in Sub-Saharan Africa: A Review', Climate, 4(47): 3-15

Tinsley, R. (2012) Rice Value Chain Analysis Sokoto State Nigeria, Volunteer Report, Washington, DC: Winrock International

Udo, R.K. (1999) The National Land Policy of Nigeria, Research Report no. 16, Ibadan: Development Policy Centre Vanguard (2018) 'Fake Cocoa Inputs as Threat to National Security', 3 January, https://www.vanguardngr.com/2018/01/fake-cocoa-inputs-threat-national-security/ (accessed 15 November 2020)

Walker, E.A. (2000a) 'The Changing Patter of Labour Relations in the Cocoa Farming Belt of South Western Nigeria, 1950s to 1990s', African Economic History, 28: 123-140

Walker, E.A. (2000b) 'Happy Days Are Here Again, Cocoa Farmers, Middlemen Traders and Structural Adjustment in South Western Nigeria, 1986-1990s', Africa Today, 47(2): 151-169

WCF (2019) Cocoa Livelihood Programme Phase II, Endline Evaluation Final Report, Washington, DC: World Cocoa Foundation, https://www.worldcocoafoundation.org/wp-content/uploads/2018/08/CLP-II-Endline-Evaluation_MainReport-051219_Final.pdf (accessed 18 March 2020) 
As part of a larger study, cross-cutting hypotheses assessed in this study (as contained in the terms of reference) are as follows:

- If the country is coastal: production and commercialisation of the crop in question are encouraged by rapidly growing urban markets. This may encourage medium and large-scale farmers to grow the crop alongside smallholders. However, incentives for production and commercialisation have been undermined in part by unpredictable competition from imports. The unpredictability of this competition comes from the fact that powerful importers have connections to senior politicians and can therefore circumvent formal rules on importation (licensing requirements, tariff payments etc).

- If the country is landlocked: engagement in the value chain by national elites takes the form of acquiring land for crop production, seeking to secure reliable market outlets and prices for their produce through manipulation of state policies, and/or orchestrating the availability of cheap inputs (e.g. fertilisers) and equipment and services (e.g. tractors) that they can 'capture'.

- If the value chain is a major source of foreign exchange for the country ( $>25$ per cent of merchandise exports): national elites seek to use the value chain as an important vehicle for distributing rents to supporters (powerful individuals and/or wider voting groups), but the magnitude of rent distribution is restrained by the importance of not 'killing the goose that lays the golden egg'.

- If production of the crop primarily takes place in sub-national regions with high population density (>200 persons $/ \mathrm{km} 2)$ : production and sale for market are both dominated by smallholder farmers, despite the interest of larger players in entering the value chain. Conversely, if production of the crop primarily takes place in sub-national regions with low-to-medium population density ( $<200$ persons $/ \mathrm{km} 2)$ : medium and,]] perhaps also, large-scale farms have expanded their production and marketing of the crop dramatically over the past decade.

- If traditional development partners have engaged actively with the value chain over the past decade: policy interventions have both been designed to stimulate commercialisation in some form or another and to facilitate the participation of smallholder farmers in the resulting commercialisation processes.

- If new development partners (e.g. Brazil, Russia, India, China, and South Africa) have engaged actively with the value chain over the past decade: policy interventions have been designed to stimulate commercialisation in some form or another, but there have been no specific efforts to facilitate the participation of smallholder farmers in the resulting commercialisation processes. 


\section{APPENDIX 2: CONCLUSIONS ON THE CROSS-CUTTING HYPOTHESES}

- As a coastal country, the commercialisation of rice production has been encouraged by a rapidly growing urban market in Nigeria. Medium to large-scale farmers have emerged to grow the crop alongside smallholders. The dominant model has been the nucleus farm and out growers model typified by Olam. The government has attempted to stem the threats of smuggled goods, particularly rice, with a prolonged border closure and by providing incentives for importers to invest in local production. In the case of cocoa, the nature of the crop as a tree crop with a long gestation period before harvest, which causes constraints associated with land tenure, has contributed to the slow entry of medium and large-scale enterprises into the value chain. Since cocoa is largely grown in subnational regions, especially in the rural areas, it has not been a consistent policy priority of the government. The cocoa value chain is therefore still dominated by smallholder farmers.

- Although cocoa is a major foreign exchange earner, its role as a source of rent distribution has been mediated by its confinement to a limited section of the country and by competing sources of foreign exchange, like petroleum and other expert crops (sesame seeds, cashew nuts, oil seeds, etc). In the last few years, it has been displaced by sesame seed as the leading export earner.

- Traditional development partners have been active in promoting commercialisation in both cocoa and rice value chains. They have designed and implemented programmes and aim to empower smallholder famers to adopt measures to improve their productivity and participate in the commercialisation process. 
Aiyede, E.R. (2021) Agricultural Commercialisation and the Political Economy of Cocoa and Rice Value Chains in Nigeria, APRA Working Paper 52, Brighton: Future Agricultures Consortium

(c) APRA 2021

ISBN: 978-1-78118-775-3

DOI: 10.19088/APRA.2021.005

\section{(cc) BY-NC-ND}

This is an Open Access report distributed under the terms of the Attribution-Non Commercial-No Derivs 4.0 Unported (CC BY-NC-ND 4.0) Attribution - You must give appropriate credit, provide a link to the license, and indicate if changes were made. You may do so in any reasonable manner, but not in any way that suggests the licensor endorses you or your use. NonCommercial — You may not use the material for commercial purposes. NoDerivatives - If you remix, transform, or build upon the material, you may not distribute the modified material. You are free to: Share - copy and redistribute the material in any medium or format.

https://creativecommons.org/licenses/by-nc-nd/4.0/legalcode

If you use the work, we ask that you reference the APRA website (www.future-agricultures.org/apra/) and send a copy of the work or a link to its use online to the following address for our archive: APRA, Future Agricultures Consortium, University of Sussex, Brighton BN1 9RE, UK (apra@ids.ac.uk)

All APRA Working Papers go through a review process before publication.

\section{Ccreative}

DO YOU HAVE COMMENTS ON THIS PAPER?

We would welcome your feedback on this working paper!

To provide brief comments, please follow this link to our short APRA Working Paper Feedback form: https://goo.gl/forms/1iVnXhhrlGesfR9

Agricultural Policy Research in Africa (APRA) is a programme of the Future Agricultures Consortium (FAC) which is

generating new evidence and policy-relevant insights on more inclusive pathways to agricultural commercialisation in sub-Saharan Africa. APRA is funded with UK aid from the UK Foreign, Commonwealth \&

Development Office (FCDO) and will run from 2016-2022.

The APRA Directorate is based at the Institute of Development Studies (IDS), UK (www.ids.ac.uk), with regional hubs at the Centre for African Bio-Entrepreneurship (CABE), Kenya, the Institute for Poverty, Land and Agrarian Studies (PLAAS), South Africa, and the University of Ghana, Legon. It builds on more than a decade of research and policy engagement work by the Future Agricultures Consortium (www.future-agricultures.org) and involves more than 100 researchers and communications professionals in Africa, UK, Sweden and USA. 